University of Nebraska - Lincoln

DigitalCommons@University of Nebraska - Lincoln

PreColumbian Textile Conference VIII /

Jornadas de Textiles PreColombinos VIII (2019)

Centre for Textile Research

$6-2020$

\title{
Middle Horizon textiles from Chimu Capac, Supe Valley, Peru
}

Amy Oakland

Follow this and additional works at: https://digitalcommons.unl.edu/pctviii

Part of the Art and Materials Conservation Commons, Fiber, Textile, and Weaving Arts Commons, Indigenous Studies Commons, Latin American Languages and Societies Commons, Museum Studies Commons, and the Other History of Art, Architecture, and Archaeology Commons

This Article is brought to you for free and open access by the Centre for Textile Research at DigitalCommons@University of Nebraska - Lincoln. It has been accepted for inclusion in PreColumbian Textile Conference VIII / Jornadas de Textiles PreColombinos VIII (2019) by an authorized administrator of DigitalCommons@University of Nebraska - Lincoln. 


\title{
4
}

\section{Middle Horizon textiles from Chimu Capac, Supe Valley, Peru}

\author{
Amy Oakland
}

\begin{abstract}
This article presents an overview of the textiles Max Uhle collected between November 4 and December 3, 1904 in the Middle Horizon cemetery at Chimu Capac in the Supe Valley, Peru. The total collection of objects numbers over 830 with 278 textiles including woven fragments, complete garments, woven and painted pouches, and over 155 painted textiles. The article discusses a sample of Chimu Capac textiles included in Uhle's Supe field Notebook 67, in his hand-written Supe report, and textiles listed in the Supe Berkeley catalog. The Chimu Capac textiles compare with collections of Middle Horizon funerary objects made in coastal burials from El Castillo, Ancon, Pachacamac, Huaca Malena, and Monte Grande. Although most of the textiles from Chimu Capac have connections with the Middle Horizon burial tradition practiced along the Peruvian coast, the painted textiles exhibit many unique features and perhaps represent a local style at the site.
\end{abstract}

Keywords: Andean textiles, Chimu Capac, Supe Valley, Max Uhle, Hearst Museum, Middle Horizon.

\section{Resumen}

Este artículo presenta una visión general de los textiles coleccionados por Max Uhle en el período entre el 4 de noviembre y el 3 de diciembre 1904 en el cementerio del Horizonte Medio del sitio Chimú Cápac, en el Valle de Supe, Perú. El número total de los objetos de la colección excede a 830, entre ellos 278 textiles incluyendo fragmentos tejidos, prendas completas, bolsas tejidas y pintadas y más de 155 textiles pintados, algunos grandes, otros fragmentados. El artículo presenta una muestra de textiles de Chimú Cápac incluidos por Uhle en su cuaderno de campo 67 de Supe, en su informe escrito a mano sobre Supe, y en la lista de textiles en el catálogo Supe de Berkeley. Los textiles de Chimú Cápac son comparables con colecciones de objetos funerarios del Horizonte Medio encontrados en entierros del Castillo, Ancón, Pachacámac, Huaca Malena, y Monte Grande. Mientras que la mayoría de los textiles de Chimú Cápac tienen conexiones con la tradición funeraria del Horizonte Medio practicada a lo largo de la costa peruana, los textiles pintados muestran muchas características únicas y posiblemente representan un estilo local del sitio.

Palabras claves: Textiles andinos, Chimú Cápac, Supe Valley, Max Uhle, Museo Hearst, Horizonte Medio.

\section{Résumé}

Cet article présente une vision générale des textiles collectés par Max Uhle entre le 4 novembre et le 3 décembre 1904 dans le cimetière de l'Horizon Moyen du site de Chimu Capac, dans la vallée de Supe, au Pérou. Le nombre total d'objets de la collection dépasse 830, entre autres 278 textiles incluant fragments de tissus, vêtements complets, sacs tissés et peints, et plus de 155 textiles peints, certains de grande taille et d'autres fragmentés. L’article présente une sélection des textiles de Chimu Capac inclus par Uhle dans ses notes de chantier 67 sur Supe, dans son rapport rédigé à la main sur Supe, et une liste des textiles dans le catalogue Supe de Berkeley. Les textiles de Chimu Capac sont comparables aux collections d'objets funéraires de l'Horizon Moyen découverts dans les sépultures d'El Castillo, Ancon, Pachacamac, Huaca Malena et de Monte Grande. Bien que la majorité des textiles de Chimu Capac ait des liens avec la tradition funéraire de l'Horizon Moyen pratiquée de long de la côte péruvienne, les textiles peints montrent de nombreuses caractéristiques uniques et représentent probablement un style local du site.

Mots-clés: Textiles andins, Chimu Capac, vallée de Supe, Max Uhle, Musée Hearst, Horizon Moyen.

DOI: 10.32873/unl.dc.zea.1205

Published in PreColumbian Textile Conference VIII / Jornadas de Textiles PreColombinos VIII, ed. Lena Bjerregaard and Ann Peters (Lincoln, NE: Zea Books, 2020). https://digitalcommons.unl.edu/zeabook/ 
Max Uhle excavated the Middle Horizon burial site known as Chimu Capac in the lower Supe Valley between November 4 and December 3 of 1904. The site ruins consist of a series of stone-walled terraces constructed against low hills approximately two miles from the Pacific Ocean (Figure 1). The hillslope and the clay soil allowed for particularly good preservation of usually perishable material and Uhle sent more than 830 objects of ceramics, wood, reed, shells, and textiles to his benefactor Phoebe Apperson Hearst during this second Peruvian expedition for the University of California, Berkeley. Uhle's hand-written site report titled "Report on my explorations in the Valley of Supe"(1) and an object catalog titled "Beginning of the excavations at San Nicolas near Supe" (2) accompanied the collection.

In addition, Uhle kept a field notebook for Supe (Figures 2,3 ) that is preserved with many of his papers, photographs, and documents at the Ibero-American Institute, Berlin. (3) In the notebook Uhle recorded 28 graves during the period from November 4 to November 14. Excavations continued until at least December 3, the last notebook entry that discusses Chimu Capac excavations (Oakland 2010). The Supe catalog continues to record all Chimu Capac excavated material. The following section provides a brief, selected account from Uhle's Supe notebook 64 .

Uhle's field notebook begins with excavations from November 4,1904 where on November 5 he describes the ceramics and textiles from Graves 1and 2 that he discovered the day before. He did not record textiles in the next two tombs, but on November 8 he discovered a complete mummy bundle in Grave 5 that he opened and described:

"the mummy was fashioned in a cylindrical packet with a cotton fabric on the outside, inside a $6-8 \mathrm{~cm}$. layer of leaves. This layer surrounded the mummy packet that was found intact, conically wrapped in skins turned inside out and tied with ropes."

He sent this "mummy package" to Berkeley along with the "false mummy head" (Oakland 2010: Fig. 9), a carved wooden monkey figure (Oakland 2010: Fig. 10), and a "work basket with contents" that included spindle whorls, bone picks, and spindles wrapped with cotton and camelid-fiber yarns. A painted textile 4-7106 (Oakland 2010: Fig. 8) was attached to the bundle stretched along the outside, the first of the 155 painted textiles that Uhle discovered at Chimu Capac.
By November 10, Uhle had collected objects in 14 graves when he began excavating what he called Mummy A from one of the deepest tombs at Chimu Capac. He photographed Mummy A with some of the 43 objects from the burial and placed one of the painted textiles 4-72210n the ground in front. This textile 4-7221 is one of the most widely illustrated from Chimu Capac (Carrion Cachot 1959: Fig 113b; Isbell and Young-Sanchez 2000: Fig. 246; Menzel 1977: Fig. 57; Oakland 2010: Fig.17). The dating of this textile is discussed in the present article below. For this tomb Uhle wrote: “The outer layers of this mummy outside the pelts were much alike those of the first mummy in leaves, with a covering of cotton cloth" and he listed twelve stuffed "Medicine pouches, painted" discovered in the tomb (Oakland 2010: Fig. 3).

But on November 14 Uhle stopped recording tomb lots. He was excavating terraces on the north slope with at least two workmen and he cataloged 43 objects in four tombs, Graves 25-28 that included the complete "Mummy in poncho" from Grave 25 that he sent in a container to Berkeley. Uhle discovered many styles of ceramics in these tombs, Wari types (Kroeber 1925: Pl.73h) in Graves 25 and 26 along with well-preserved painted textiles (Oakland 2001; 2010). The stuffed, painted pouches in Grave 25 and double cloth pouches in Grave 26 are similar to the dozens of pouches with pendant bags that formed a large part of preserved textiles in Chimu Capac burials. Uhle appears to have abruptly stopped working at Chimu Capac on November 14 . He left the notebook page empty and when he began writing again on the next page it was to record columns of measurements, probably for a site plan. The Berkeley catalog also stopped in the middle of the page at the same last object 7213a. The catalog list began on the next page with a different system of recording in a different handwriting, possibly that of his wife Charlotte Grosse who he had married directly before this second Peruvian expedition. Several objects that he cataloged in the notebook on this day were never given the same field numbers, but instead were given new numbers later in the catalog. John Rowe (1959:11) reported that while in Supe, Uhle received a letter from Phoebe Hearst telling him that she would be terminating his employment after the present expedition. His future plans were undoubtedly placed in a precarious position at this moment with the unexpected news. The letter must have arrived November 14, 1904.

But the excavations at Chimu Capac continued and the Berkeley catalog begins to lists hundreds of objects by type

1. Max Uhle, 1905a, Supe Report. "Dr. Uhle, Expedition to Peru, Received from Mrs. Hearst Oct. 17 “/o5”.

2. Max Uhle, 1905b, Berkeley Catalog. "Sent with Cuzco report and Uhle catalogue".

3. Uhle Notebook 67, legacy of Max Uhle, Published with the kind permission of the Ibero-American Institute, of the Prussian Cultural Heritage Foundation, Berlin. Quotes are from an English translation that Heiko Prümers prepared and generously allowed me to use. 


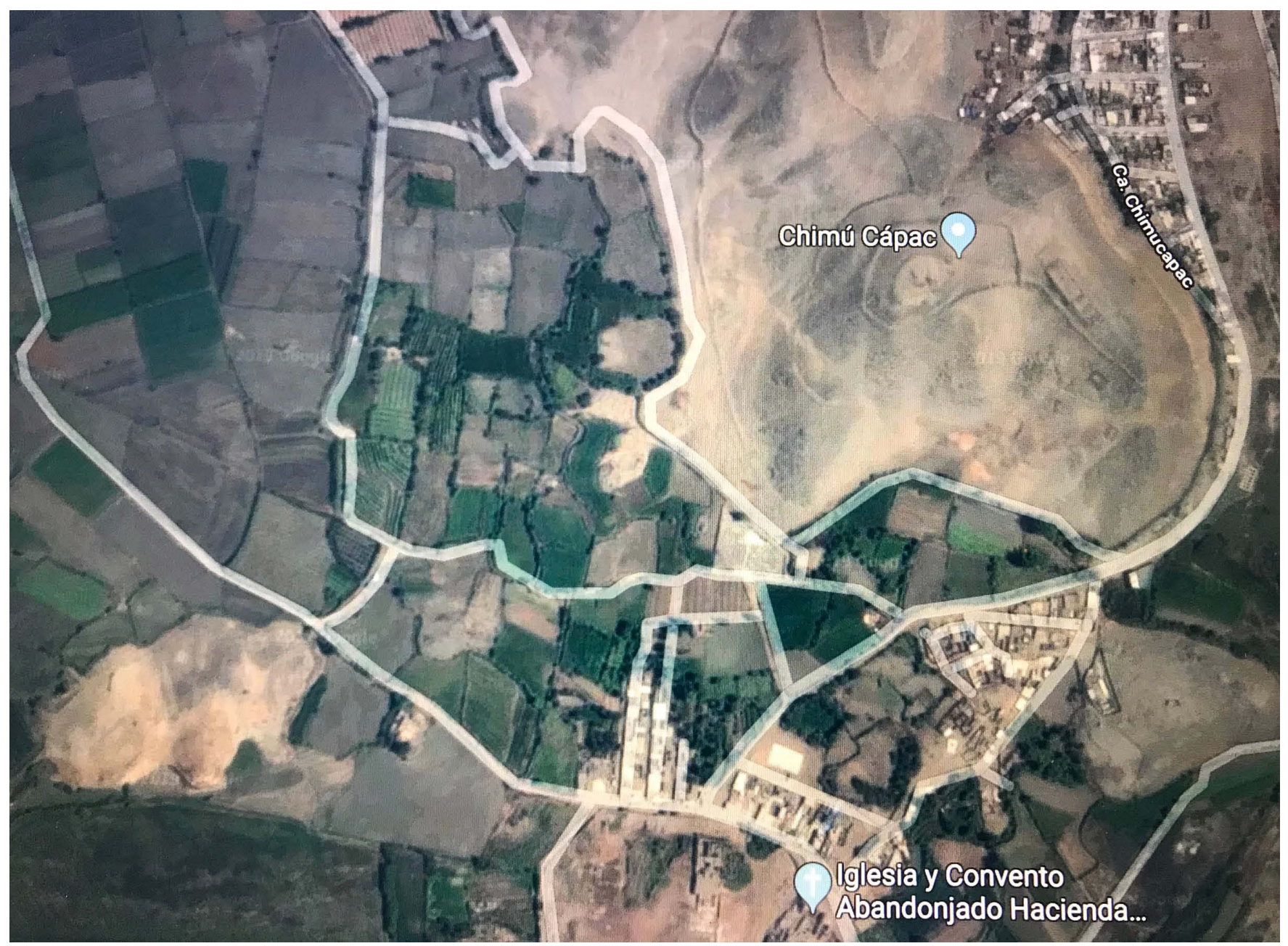

Figure 1. Google Map, 2019, Digital Imagery. Lower Supe Valley, Peru. Photo Amy Oakland.

instead of grave lot. While Uhle filled the following notebook pages with measurements he may have also used this time to excavate the "Chimu cemetery at Oliva" and the "Cemetery Puerto de Supe". Material of both these sites was added to the catalog. The Berkeley catalog continued with the object number 7214 listing large ceramic jars followed by other ceramic types. Textiles were grouped in categories such as "Tapestry fragments", "Double stuff", and "Painted textiles". Uhle returns to catalog the last objects arriving from excavations at Chimu Capac and these final catalog entries appear to be listed as tomb lots just as they were listed at the beginning of the Berkeley catalog. At this late period of the catalog Uhle brackets material related to Graves 4, 5, and 6 that Alfred Kroeber (1925) illustrated in his monograph about Uhle's ceramics from Supe.

The Chimu Capac excavations ended during the first week of December 1904. On notebook page 33 Uhle writes:

"3 December. This week Esteban and Eduardo continued the excavation at San Nicolas by themselves, because the type, the chronological position and the way of interment are the same in all the burials. Furthermore it is a useless waste of energy to sit quietly next to them in the great heat. They do have the following successes: 1 . nearly pure Tiahuanaco and related epigonal-style vessels; 2 . new types, beaker with faces, heads of cats, monsters etc.; 3 . some vessels that are identical with the oldTrujillo types. So there are in touch at Chimu Capac: Tiahuanaco, Epigonal, South to North and old Trujillo, North to South; 4. high quality epigonal textiles, among others such as those with sketchy abundant figurative painting; 5 . at least one fine tapestry, that is nearly pure Tiahuanaco."

With this last entry Uhle established that Chimu Capac was exactly what he reported in the Supe Report (discussed in this article below): a densely packed cemetery stacked so 
5. November 1904, San Nicolas

Excavation on the $2^{\text {nd }}$ terrace with the stone walled graves continued with two workmen. Yesterday with a workman we worked over there alongside a wall built up by two rows of stone under which we found burials that had been removed from their original position and had been placed under the wall without a pattern. The replacement may have happened in ance left the pottery with the burials and huaqueros wouldn't have put back the remains (bodies only partial, mainly only heads) into the ground. The time of the original burials was the later northern epigonal period. Remains 7055 - 7067.

We have searched for original stonewall-cists. Those are exquisitely built of quarried stones and mud mortar, the level side of the stones looking inside. One such empty grave was $1.35 \mathrm{~m}$ long, $1 \mathrm{~m}$ wide, aproximately $2 \mathrm{~m}$ deep, others are narrower and longer, otherwise in nearly all other forms up to nearly squares. General direction N-S.

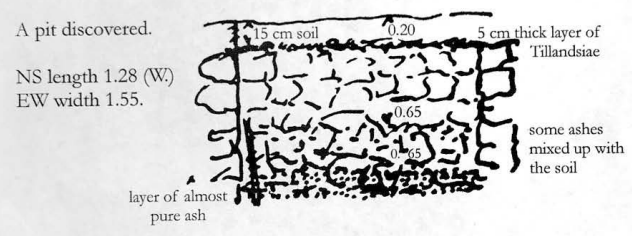

Depth $1.55 \mathrm{~m}$. [In the] SW-corner was found a board with fishes that served as a lid; beneath: 7075

Wooden bird (7081), boards in the shape of combs, snakes from wood, also human faces made from boards, sticks wrapped with yarn [page 2] (higher, in the layer of ash and the earth of the grave there was found a beaker (7069) (broken) and a bottle, black and coarser, but with rests of reliefs). 7068

I silverplate, painted board, all of it lay next to the southside of the pit

I bowl with some pattern on the outside, a comb (broken)

I spindle, little balls of yarn for weawing

I Spondylus sp. shell, 1 conchita shell with paint, 1 condor head - wood.

Total contents:

7068 black bottle with reliefs

7069 black beaker with reliefs broken

Figure 2. Max Uhle, Supe Notebook 67, p.1. Translated by Heiko Prümers. Published with kind permission of Heiko Prümers and the Ibero-American Institute, of the Prussian Cultural Heritage Foundation, Berlin. Photo Amy Oakland.

full that mummy bundles intruded one upon the other. He described and illustrated at least two mummy bundles in his notebook (Figure 3) and he sent to Berkeley three more complete mummy bundles where they remain unopened.

\section{Max Uhle Supe Report: Chimu Capac Site and Chronology}

Uhle chose to excavate Chimu Capac after a reconnaissance of the Supe and Pativilca valleys. He thought that the site was part of a town from the Tiahuanaco period and his Supe report makes it clear that the excavations were focused on burials.

"The various platforms of the principal building in the enclosure next to the hills are densely occupied by burials, which are missing only where the natural underlying rock is too near to the surface of the artificial constructions. The

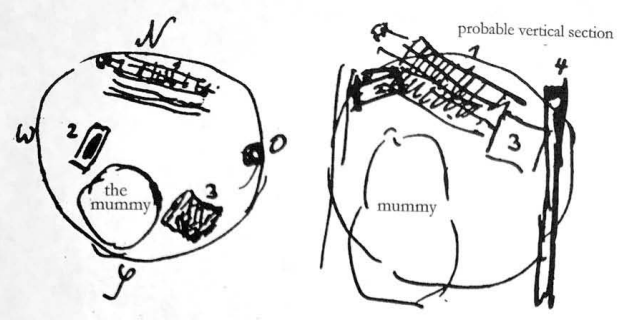

$4 \mathrm{a}$ big bole that stands upright at the east side of the grave, starting about a meter under the surface level and ist lower end [page 5] pointing to the North.

In 2 meters depth

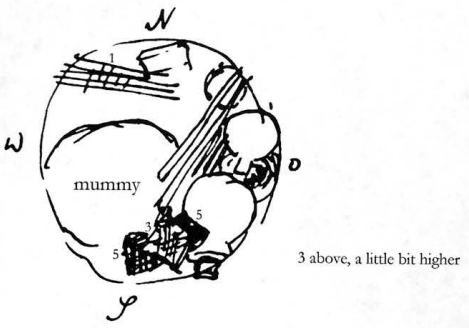

No. 3 was removed by the boys. Beneath was discovered only a similar plaiting-work, a real basket 5 .

Beneath the jars still more medium-sized bottles, bowls, one of those in the extreme N.E. filled with beans, maize and pods of pacay.

-7105 various bundles of reed

7114ab wooden box $(=2)$ with lid

$-7115 \mathrm{ab} 2^{\text {nd }}$ wooden box found deep on the N. side, containing 2 rolls

Figure 3. Max Uhle, Supe Notebook 67, p. 4. Translated by Heiko Prümers. Published with kind permission of Heiko Prümers and the Ibero-American Institute, of the Prussian Cultural Heritage Foundation, Berlin. Photo Amy Oakland.

burials follow two types: that of square chambers of masonry of stone, which contain one or two mummies, or that of mummies embedded with all their utensils without other provision in the soil. There is also a transitional type of burials, mummies placed into the ground near stone walls which utilized for one side of the grave" (Uhle 1905: 6-7).

He understood the site's chronology because he discovered that it compared to his earlier excavations at Pachacamac: "There is no other locality on the whole coast of middle Peru with so many remains reaching back to the period of Tiahuanaco or its immediate neighborhood, besides Pachacamac explored by me in 1896, than the ruins of 'Chimu Capac' near San Nicolas" (Uhle 1905: 5-6). But he states that unlike Pachacamac that continued to be used for burials through the Inca period, Chimu Capac was 
abandoned long before the Chimu and Inca entered the Supe Valley. This relatively short period of occupation is one of the very important aspects of Uhle's excavations at Chimu Capac. Later Sican and Chimu period material has been discovered in many similar funerary sites such as Pachacamac and Huaca Malena, but not material from this later period at Chimu Capac.

The most unique and probably "local" aspect of the site is the presence of an unusual quantity of painted textiles. Uhle (1905: 7-8) reported about this exceptional collection: "These are large common cotton clothes painted all over with mythological and talismanic designs. The collection contains an especially large number of them." He compares them to painted textiles from Ancon: "In the widest sense their technical appearance is nearest to that of the so called 'grave-tablets' of Ancon, a few of which are also represented in my collection from Ancon". Uhle had arrived in Supe in 1904 following his excavations in Ancon and Chancay.

Painted textiles have been discovered in other Peruvian locations, but the collection that Uhle made at Chimu Capac appears to have been the largest ever uncovered at any single site. Uhle's Supe report written directly to Mrs. Hearst gives more information about the finding circumstances of the painted textiles than anything he wrote in his notebook or catalog. Uhle (1905a: 9-10) tells Mrs. Hearst that he found them:

"laid upon the floor of the grave under the mummy or above upon its head outside of the mummy bale, if not inside of its exterior packing. Occasionally the mummy bales were found enveloped in one or more of such cloths. On others they were missing. One mummy was placed upon one large cloth of this kind while two other large ones were laid over it, and 16 smaller ones all with different signs were folded and arranged as in a storeroom one above the other above the head of the bale. Though only a small number of these cloths are now intact, all together they place a great variety of religious ideas before our eyes."

\section{Former Research}

Alfred Kroeber (1925) was the first to publish a monograph of Supe ceramics. Dorothy Menzel (1977) examined the larger group of collections that Uhle made for the University of California and discussed Chimu Capac as an important and "strategic" Wari center, however Menzel (1977:30) noted: "The platforms of the terraces of the pyramid at Chimu Capac were used as cemeteries, like the terraces of the Huaca del Sol in the Moche Valley, and like the forecourt of the Huari temple of Pachacamac". This feature appears to be repeated in other locations during the Middle Horizon where burials have been placed over earlier religious constructions in the Asia Valley over an Early Intermediate Period structure at Huaca Malena (Angeles and Pozzi-Escot 2001) and over the Moche Huaca Cao in the Chicama Valley (Oakland and Fernandez 2001; Oakland and Fernandez 2005). Menzel (1977:29-30) determined that Chimu Capac collection contained material representing all epochs of the Middle Horizon, but most from $\mathrm{MH} 2 \mathrm{~B}$ and 3. Menzel's description of the site as an important Wari outpost and settlement was influenced by Uhle's Supe report where he described Chimu Capac's terraces as part of an "old town”. Lisa Valkenier (1995) excavated the site and found no evidence of a Wari occupation at Chimu Capac. She did identify the Early Horizon temple constructions that formed the foundation for the site. (4)

Lila O'Neale (1933) was the first to examine and publish Chimu Capac textiles. She analyzes a single textile 4-7827 illustrated in Menzel (1977: Fig.76-76B) and in color in Isbell and Young-Sanchez (2012: Fig. 248). The textile is an elaborate sleeved cotton and camelid-fiber shirt woven in different patterns and multiple structures including discontinuous warp and wefts, supplementary wefts, cotton plain weave, and slit-tapestry for the border hem and sleeves. O'Neale noted that the shirt was woven in twelve individual textiles that she thought could have been created by different weavers and that the shirt had been torn in half lengthwise. O'Neale completed large preparatory drawings of the Chimu Capac painted textiles, nine that were published by Rebecca Carrion Cachot (1959). (5) Ina VanStan (1995) completed a general survey of the plain weave structure of the Chimu Capac painted cloth identifying the unusually large variation in spin and weave configurations.

4. Valkenier 1995 cited Kroeber 1925 not Uhle's 1905 Supe Report and stated, without evidence, that Uhle worked a few days and purchased material. She also stated that there were no other associated field notes or documents when, in fact the Ibero-American Institute, of the Prussian Cultural Heritage Foundation, Berlin houses photographs, personal papers, and field notes.

5. Carrion Cachot (1959) published the following figures that relate to O'Neale's drawings of Chimu Capac textiles: Fig. 113a: 4-7443; 113b: 4-7221; Fig. 115: 4-7282; Fig. 117a: 4-7449; Fig. 117b: 4-7165; Fig. 118a: 4-7225; Fig. 118b: 4-7224; Fig. 119a: 4-7276; Fig. 119b. 4-7281. 


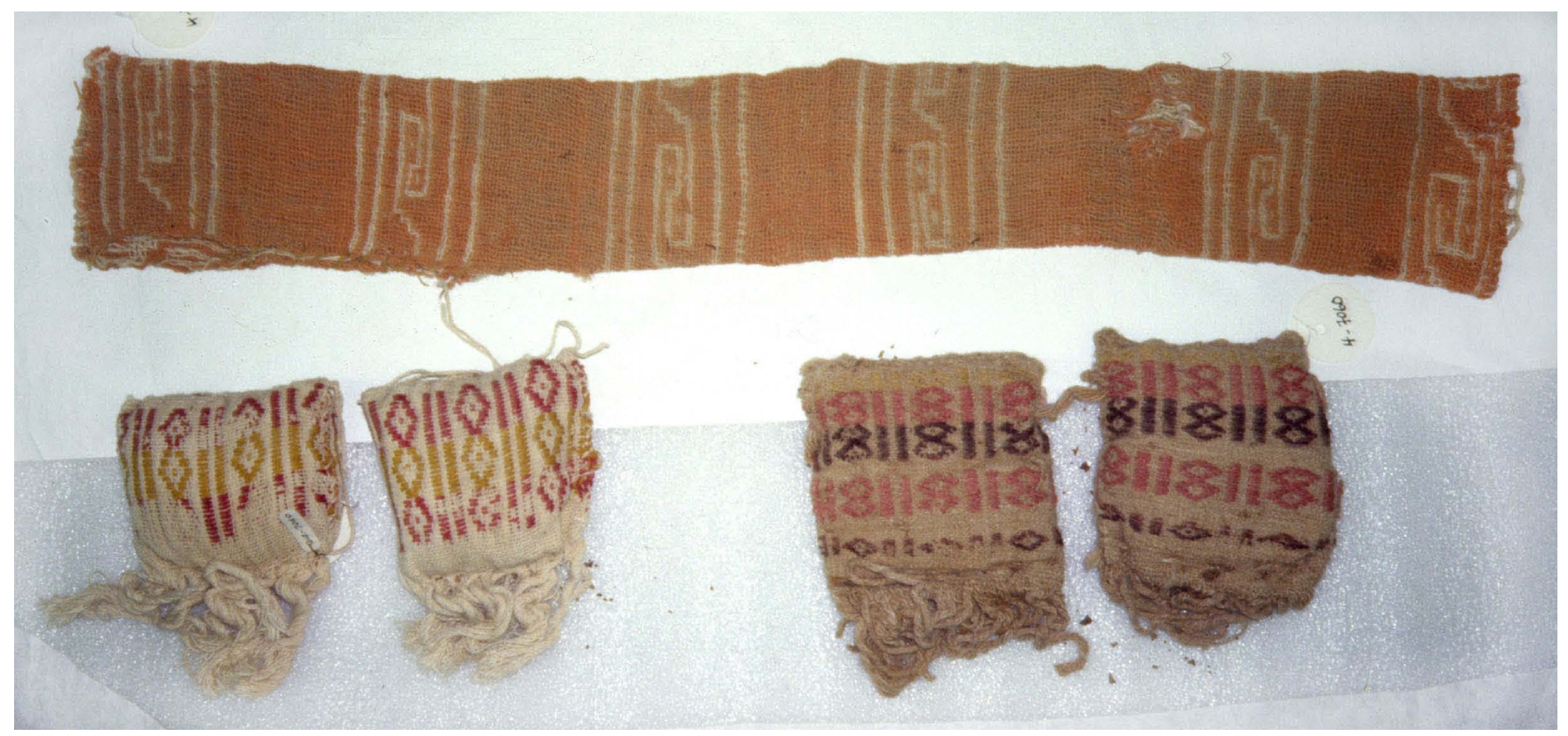

Figure 4. Grave 1, flat pouch 4-7057A (top) woven in incomplete double cloth and (bottom) 4-706o, four bags woven with supplementary-weft patterning. Courtesy of the Phoebe A. Hearst Museum of Anthropology and the Regents of the University of California. Photo Amy Oakland.

\section{Textiles in Chimu Capac Graves and in the larger Collection}

Uhle's notebook, report, and catalog identify that Chimu Capac was a large cemetery and that Uhle and his workers spent most of the month of November 1904 excavating burials in stone walled terraces. All of the textiles appear to relate to Middle Horizon types similar to those known from Uhle's own excavations in Pachacamac and to others that he knew from Ancon and that have now been identified from El Castillo in the Huarmey Valley (Prümers 1990; 1995; 2001) and Huaca Mallena in the Asia Valley (Angeles 2017; Angeles and Pozzi-Escot 2001; Frame and Angeles 2014). The textiles that Uhle described for the first Grave 1 relate exactly to the larger collection of textiles recovered at Chimu Capac.

\section{Pouch 4-7057 and Pendant Bags 4-706o}

Uhle gave three catalog numbers to the six textiles from Grave 1. He listed the long ( $44.5 \times 5.8 \mathrm{~cm}$ ), flat textile (Figure 4, top) 4-7057 "Double stuff" and cataloged the four small pouches (Figure 4, below) together as 4-7060 "Yellow pouch". (6) The flat double cloth textile was woven in incomplete double cloth with ochre and white Z-spun single yarns. The textile was folded and sewn together and may have been placed in the grave without stuffing. The four small bags called "Yellow pouch" 4-706o were woven in Z2S-spun camelid fiber and cotton and patterned with supplementary wefts in diamonds and bars. The bags were created as pairs. The first two $(6 \times 6 \mathrm{~cm}$. $+6 \mathrm{~cm}$ fringe) have a lighter white cotton warp and brighter yellow and red camelid fiber in the wefts. The second pair $(8.4 \times 7 \mathrm{~cm}+3-4 \mathrm{~cm}$ fringe) were woven on a darker tan cotton warp with yellow, pink, and dark purple dyed camelid fiber in the supplementary wefts. Each pair were finished on each loomend and cut in the middle with the cut warps forming the fringe. They were folded and sewn along the side and bottom above the fringe, stuffed with unspun cotton, and sewn closed along the top. Similar bags were attached as pendant to pouches in the collection, but these four may have been placed in the grave as separate bag offerings.

\section{Pouch 4-7057A with pendant bags}

Uhle called the Grave 1 textile 4-7057A "Red, ochre pouch" (Figure 5). The Z2S white cotton plain weave textile (47 $\mathrm{x} 7 \mathrm{~cm}$ ) appears to have been dyed, rubbed, or painted with an ochre pigment, folded, sewn, and finally stuffed with unspun white and brown cotton. Three small pendent pouches $(12 \times 8 \mathrm{~cm})$ were woven with natural brown and

6. The flat textile now labeled 7060 should be Uhle's "double stuff" 7057. The catalog number 706o and title "Yellow pouch" must be the four small pouches with bright yellow dyed camelid fiber. 


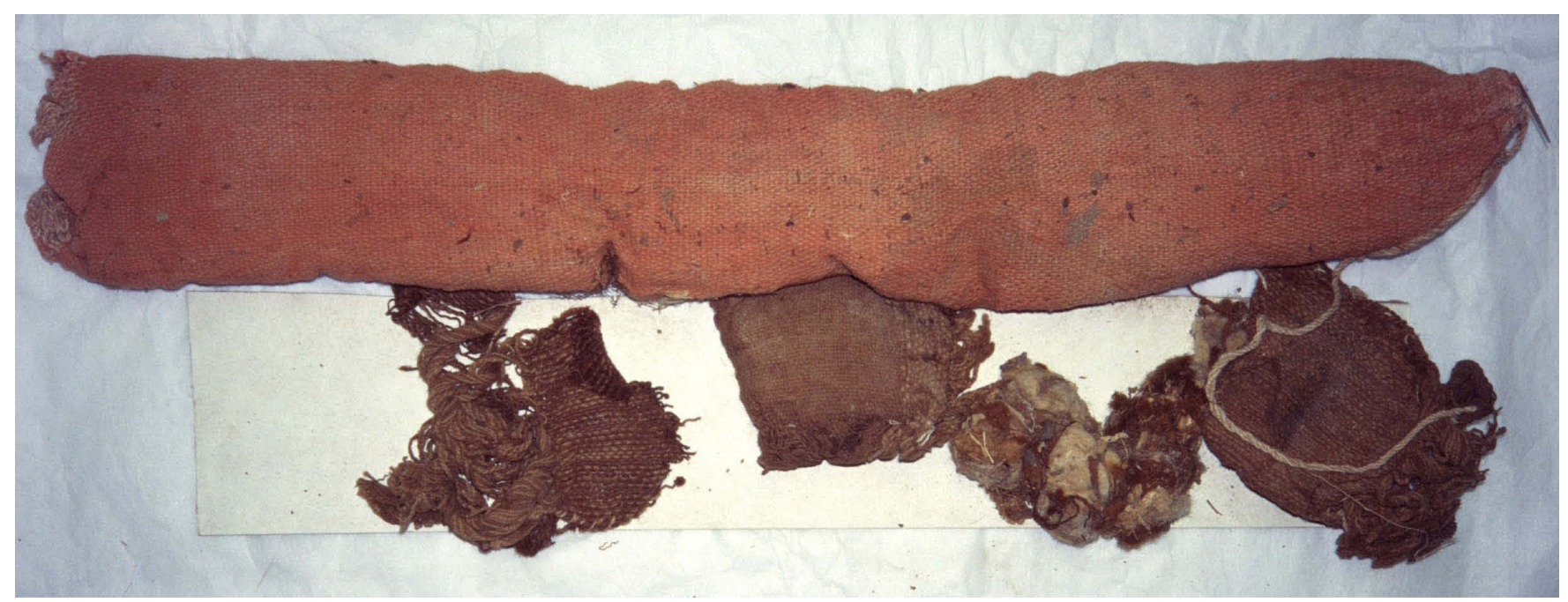

Figure 5. Grave 1, 4-7057 stuffed pouch, pigment-dyed orange with three brown cotton pendant pouches. Courtesy of the Phoebe A. Hearst Museum of Anthropology and the Regents of the University of California. Photo Amy Oakland.

tan cotton Z2S plain weave and cut from the loom leaving an unwoven portion to become fringe, sewn closed, and stuffed with unspun cotton.

These pouches from the first Grave 1 relate closely to twenty-six similar pouches that Uhle excavated, fourteen in the first 28 graves at Chimu Capac. All are woven in cotton plain weave or in double cloth and the pendant bags are woven in plain weave, double cloth, and in supplementary weft-patterning. Painted designs decorate at least eleven pouches and pendant bags (Oakland 2010: Fig. 3).

\section{Painted Pouch 4-7283 from Grave 25}

Uhle collected two well-preserved pouches in Grave 25, 4-7283 and 4-7286 "lying under the mummy". The long $(107 \times 9.9 \mathrm{~cm})$ "Painted medicine pouch" 4-7283 (Figure 6) was woven in $\mathrm{Z} 2 \mathrm{~S}$ cotton plain weave and painted before folding with interlocking frets in brown and bright orange leaving the white cotton surface as an outline around the images. The cloth was folded, sewn closed, and stuffed with unspun cotton and leaves. Seven pendant bags (8-11 x $6.5-8.5 \mathrm{~cm}$ ) were added along the sewn edge, each woven on one loomend, removed and folded, with the unwoven portion creating an un-cut fringe. All yarns are Z2S spun and in two bags dark brown and white cotton were woven in a checked plain weave pattern. Five pouches were painted with grey fret designs. This pouch has been dated to $\mathrm{AD}$ 940-1020. (7)

\section{Painted Pouch 4-7773 and bags 4-7775 from probable} Grave 32

Uhle collected a finely woven and painted pouch 4-7773 $(51 \times 13.5 \mathrm{~cm})$ (Figure 7) together with a series of textiles that appear to be a tomb lot related to the Wari tunic 7771 described below. The pouch has been painted in solid brown in large step images leaving the white $\mathrm{Z} 2 \mathrm{~S}$ plain weave for contrast. Three pendant pouches woven in log-cabin in plain weave have been preserved, each created with different cotton colors in brown and white, light brown and white and one woven with white cotton and dyed red camelid fiber.

The bags that Uhle cataloged as 4-7775 A and B (Figure 8) appear similar in color to other textiles in the same Berkeley catalog series suggesting that they are also part of a tomb lot Grave 32. The bags $(11.5 \times 8.5 \mathrm{~cm}$. and $14 \times 18.5$ $\mathrm{cm}$ ) have been woven with $\mathrm{Z}$ spun white cotton in warp and weft along with supplementary paired $\mathrm{Z} 2 \mathrm{~S}$ yarns in red and very dark green-black camelid fiber. The supplementaryweft pattern is very similar to the small bags 4-706o (Figure 4 from Grave 1.

These examples are a sample of the 28 pouches and bags that Uhle excavated at Chimu Capac. Similar pouches have been recorded from Middle Horizon burial sites from the central and south coast in Ancon (Reiss and Stübel 18801887:Pl. 72; Young-Sanchez 2006: Fig. 7) and in Pachacamac (Kaulicke 2001: Fig 2 "momia de atras"; VanStan 1967). Ann Rowe (1986) described small bags with diamond and

7. The painted pouch 4-7283, Grave 25 yielded age 980+-40 for CAMS55928. CAMS, Lawrence Livermore National Laboratory, June 1 , 1999. "Quoted age is in radiocarbon years using the Libby half life of 5568 years and following the conventions of Stuiver and Polach, Radiocarbon, v. 19, p.355, 1977”. 


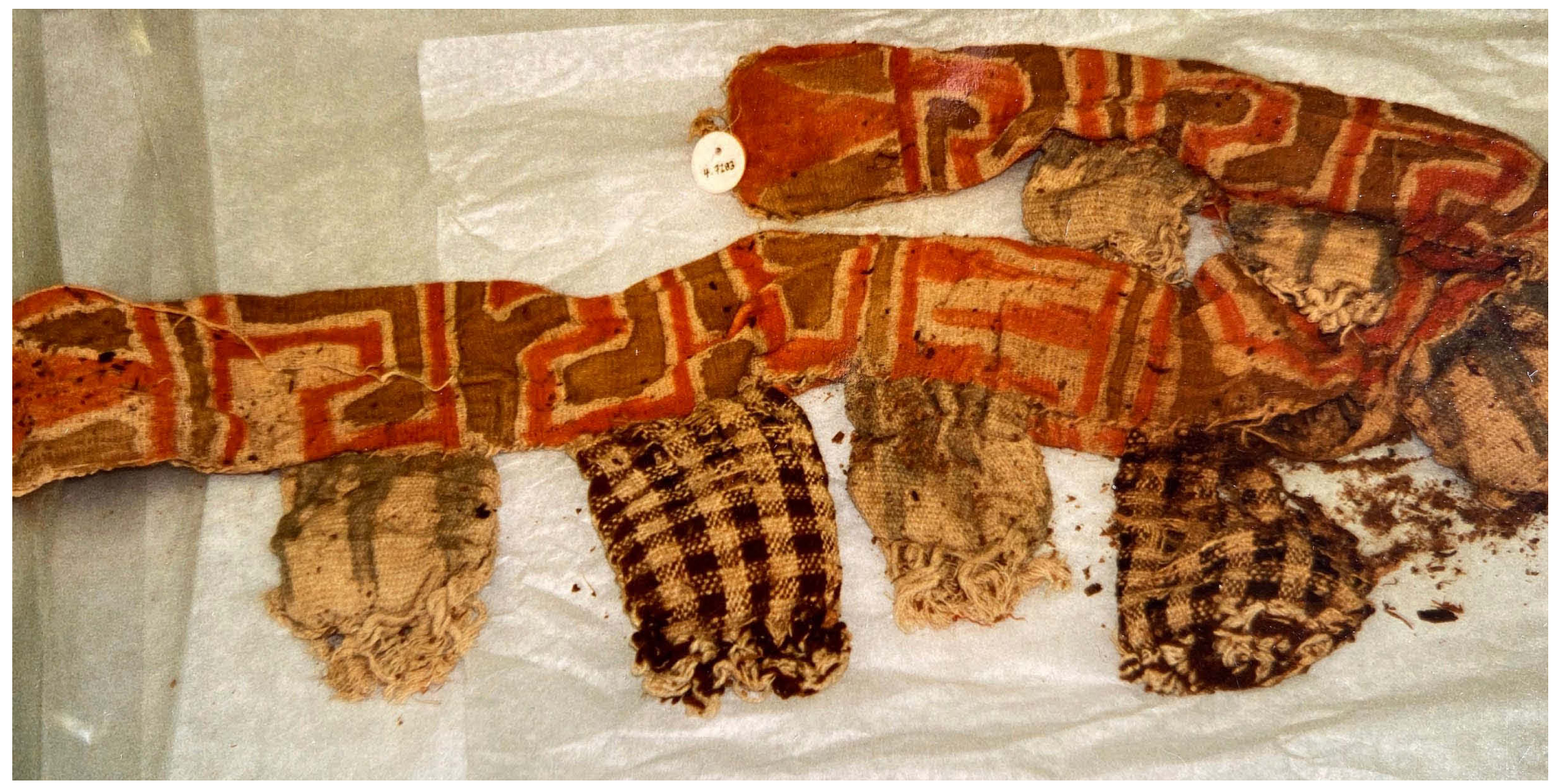

Figure 6. Painted pouch with pendant pouches 4-7283 discovered next to the mummy bundle in Grave 25. Courtesy of the Phoebe A. Hearst Museum of Anthropology and the Regents of the University of California. Photo Amy Oakland.

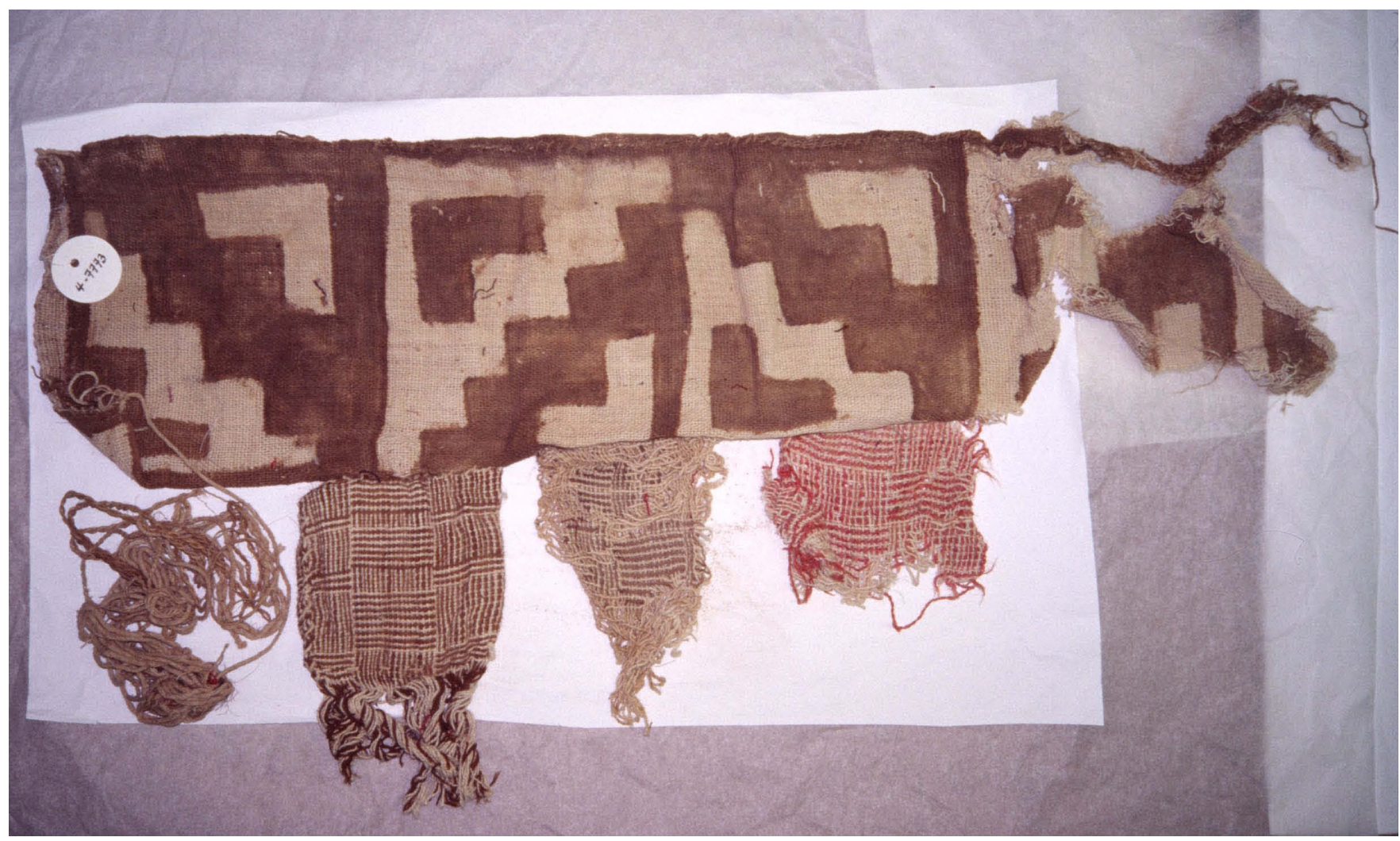

Figure 7. Painted pouch with pendant pouches 4-7773 found in possible Grave 32. Courtesy of the Phoebe A. Hearst Museum of Anthropology and the Regents of the University of California. Photo Amy Oakland. 


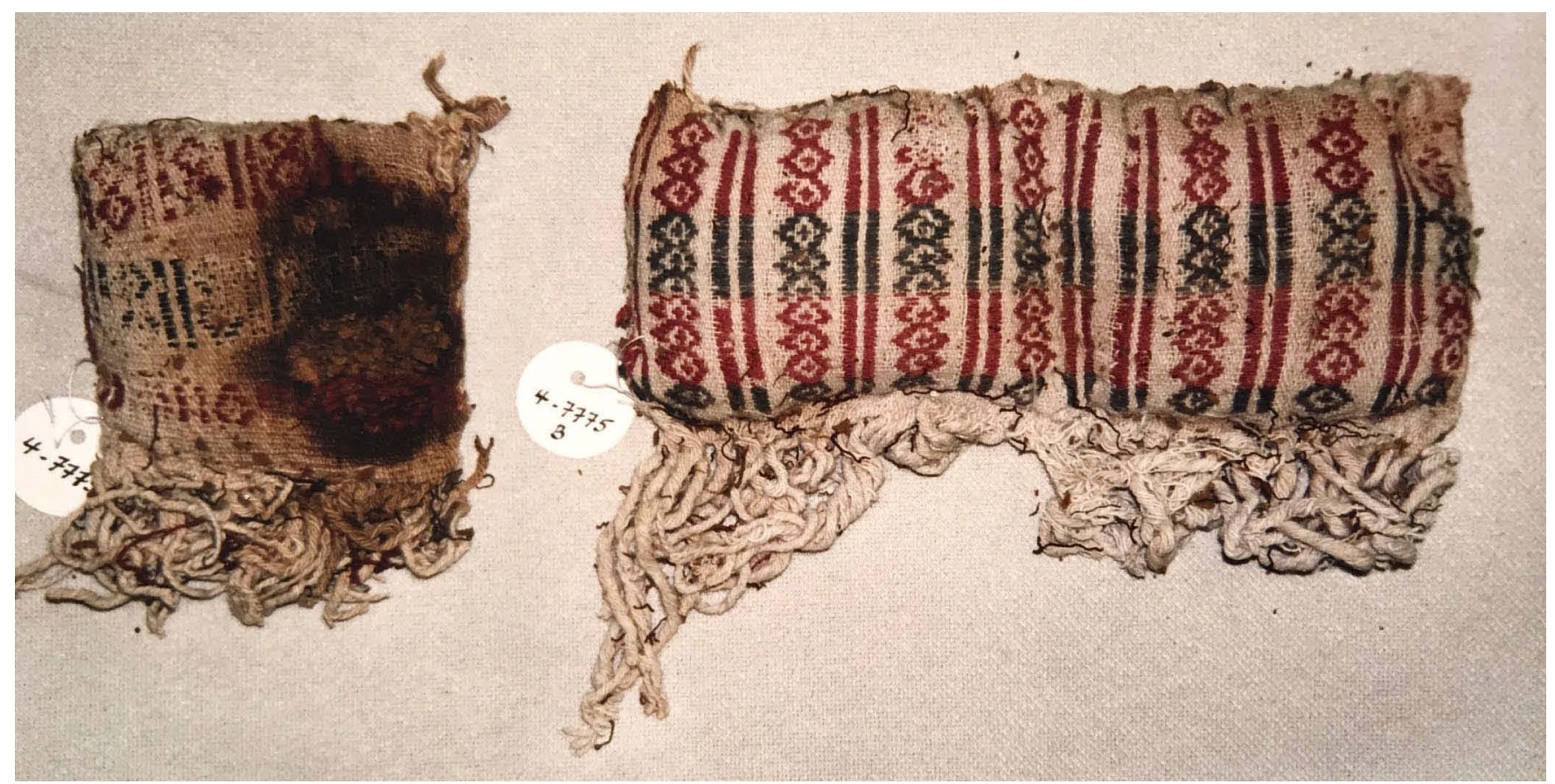

Figure 8. Small bags 4-7775 woven in plain weave with supplementary weft patterning found in possible Grave 32. Courtesy of the Phoebe A. Hearst Museum of Anthropology and the Regents of the University of California. Photo Amy Oakland.

bar designs in supplementary-weft patterning from Monte Grande in the Nasca Drainage that are very similar to the four small bags 4-706o from Grave 1 and to the small bags just described 4-7775 A and B.

Elite Chimu Capac burials that Uhle excavated at Chimu Capac must have originally appeared like those Uhle photographed at Pachacamac such as "Momia de frente" and "Momia con tapiz" (Kaulicke 2001: Fig. 1 and 5) and those illustrated by Reiss and Stübel (1880-1887: Pls. 15-17) from Ancon. Margaret Young-Sanchez (2000) compared many Ancon textiles to Chimu Capac such as the weft-interlocked Wari tunics, shirts woven in discontinuous warp and weft technique, and also large, all camelid fiber shirts from inside the mummy bundles, the scarves wrapped around the bundle's neck, and mummy pouches.

These excavations in Late Middle Horizon cemeteries identify elite burials with the individual's flexed body wrapped and packed with leaves, llama pelts, and ropes. The outside is covered with decorated clothing, a false face, headcloth, or headdress. At Chimu Capac Uhle lists many objects that were associated with funeral bundles such as carved and painted wooden faces cataloged as "False head of mummy" 4-7412 (Menzel 1977: Fig. 45), "False mummy head" 4-7116 from Grave 5 (Oakland 2010: Fig. 9), and another "False head of mummy" 4-7410 (Figure 9) similar to three more in the collection. These faces were carved from a single wood block with the nose in high relief and diamond-shaped eyes and mouth indicated in shallow carving. Eyes are painted white and black and the surface has been coated with a resin-like red pigment. The unpainted forehead would have been covered with a headband or cloth headdress.

Chimu Capac Men's Headdresses 4-7623, 4-7435 and 4-7435A

Uhle cataloged many headdresses like the "Red woolen crown" 4-7623 $(13.3 \times 24 \mathrm{~cm})$ (Figure 10) that was created with groups of long gold-colored loosely spun Z2S camelidfibers. The band was knotted with square knots in alternate rows into a circle that was dipped into red dye. The band's appearance seems to give an impression of hair or feathers, or perhaps both were intended. At least four "crowns of reeds" like 4-7435 (Figure 11) and 4-7435A (Figure 12) identify two different styles of plaited men's headbands. The heavier, solidly plaited band 4-7435 $(23.5 \times 15.2 \mathrm{~cm})$ has been folded and may have been placed in this form in the burial. Uhle describes finding "plaited crowns" in Grave 5 placed next to the mummy bundle and on the shoulder of the bundle. The openwork headdress 4-7435A is plaited with fine reed $\left(55^{+} \times 15.4 \mathrm{~cm}\right)$ and has been preserved in fragments. Each of these plaited headdress styles have been identified in Middle Horizon cemeteries at Huaca Cao (Oakland and Fernandez 2001: Fig. 8), El Castillo (Prümers 1990: 


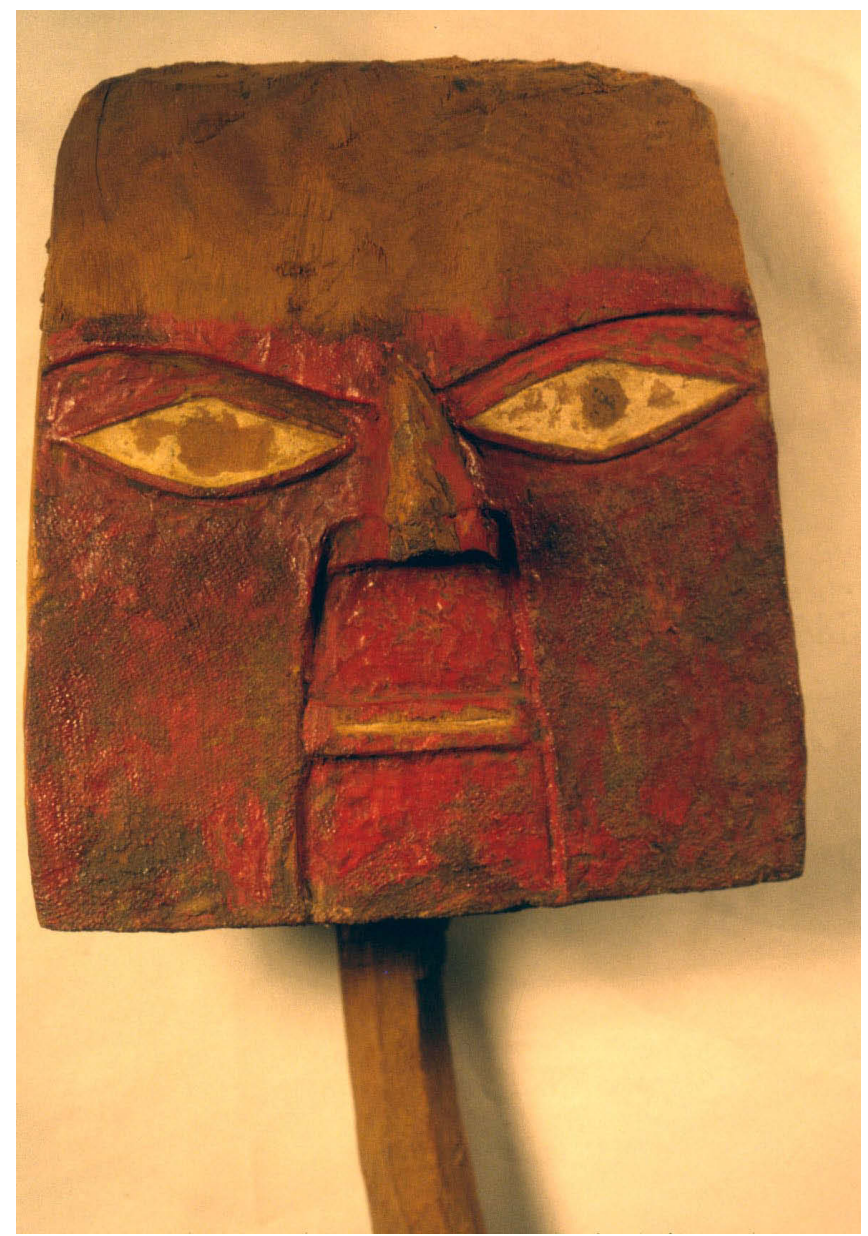

Figure 9. A carved and painted wood head or "mummy face" 4-7410 excavated in burials at Chimu Capac. Courtesy of the Phoebe A. Hearst Museum of Anthropology and the Regents of the University of California. Photo Amy Oakland.

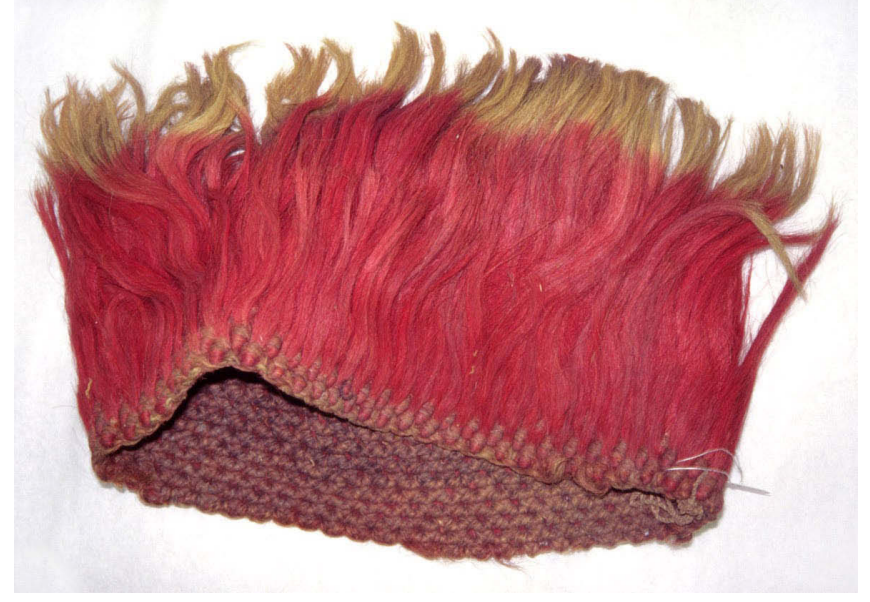

Figure 10.Knotted pile headdress 4-7623 dyed red cataloged "red woolen crown". Courtesy of the Phoebe A. Hearst Museum of Anthropology and the Regents of the University of California. Photo Amy Oakland.

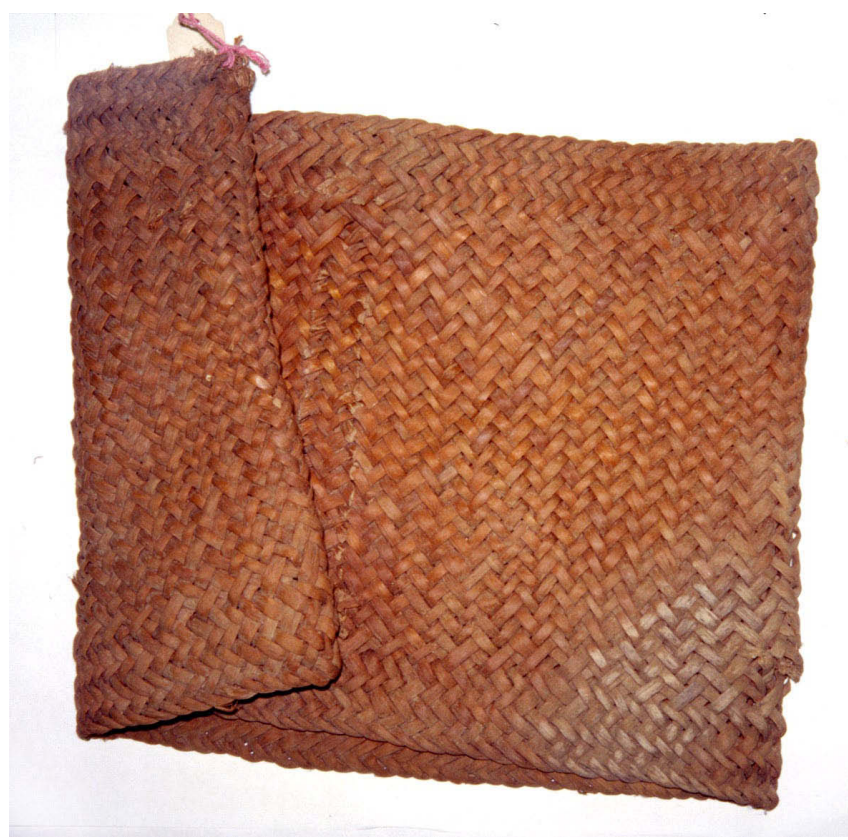

Figure 11. Reed plaited man's headdress 4-7435. Courtesy of the Phoebe A. Hearst Museum of Anthropology and the Regents of the University of California. Photo Amy Oakland.

Figs. 209-213; 2001: Fig. 26), and Huaca Malena (Angeles 2017: Figs. 4A-C and 5).

Uhle also collected headdress ornaments such as "bunch of plumes" 4-7708 (Figure 13) created with yellow feathers each wrapped with red Z2S camelid yarn attached at the base with reed. Uhle cataloged other headdress types like "ornament of flamingo feathers with headband", "knotted crown", and long red pile cords like similar headdresses described by Angeles (2017) from excavations at Huaca Malena.

\section{Wari Tunics 4-7825 and 4-7771 and Wig 4-7772}

Even before his own excavations in the cemeteries of Ancon and Pachacamac, Uhle had studied Peruvian textiles in Berlin. He was familiar with Middle Horizon textile types and in the Supe catalog he lists textiles with descriptive terms that often identify both textile construction and garment type. For example, he lists a Wari weft-interlocked tunic 4-7825 (Figure 14) as "Large red and yellow tapestry poncho", one of four different weft-interlocked tapestries collected at Chimu Capac. The Wari tapestry tunic 4-7825 was cut along each side-seam and opened for burial and the neck slot was stitched closed. As with most Wari tunics the warp is aligned horizontally as worn, the tunic is made in two separate parts, the textile is cut from the loom with one 


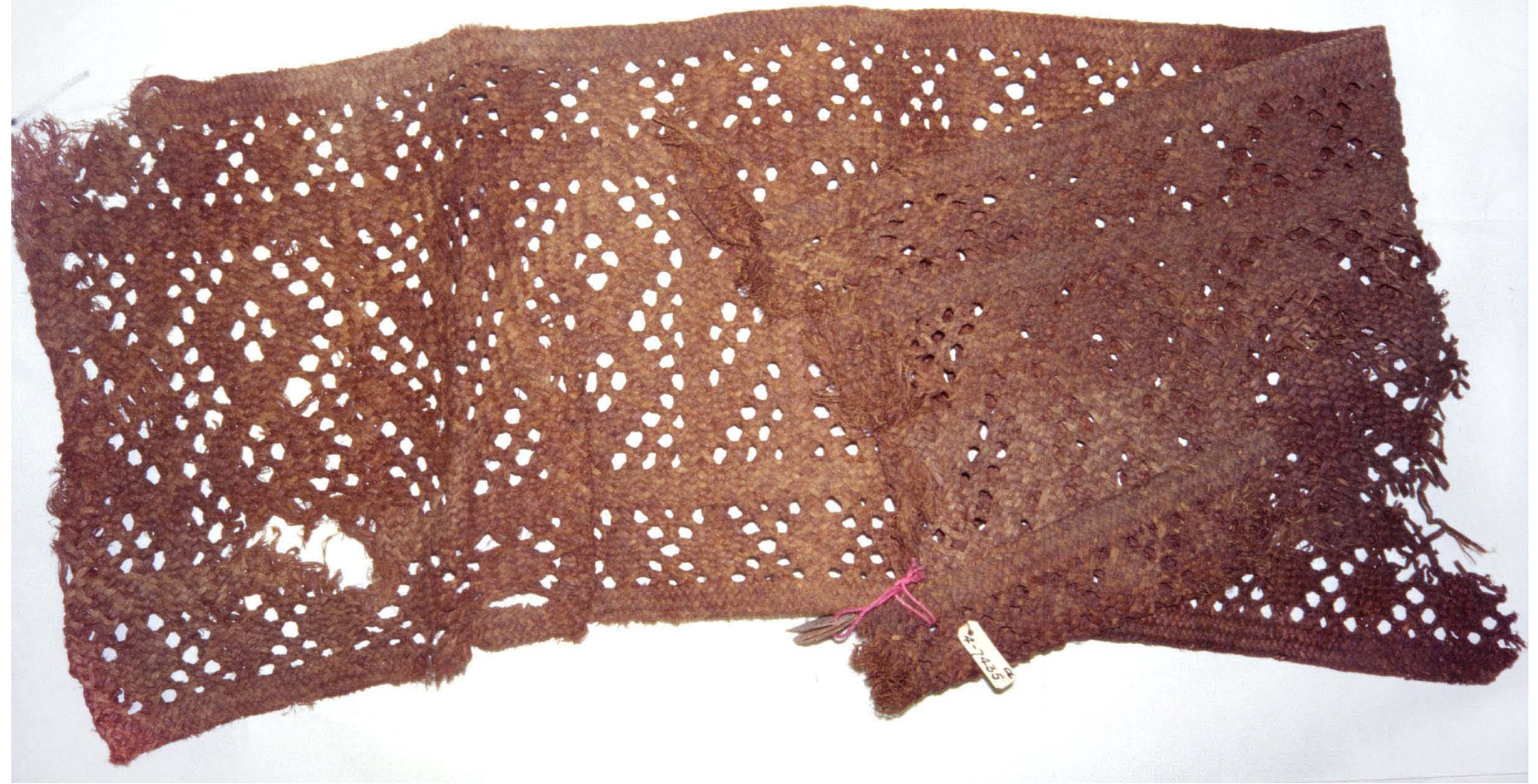

Figure 12. Plaited man's headdress 4-7435A. Courtesy of the Phoebe A. Hearst Museum of Anthropology and the Regents of the University of California. Photo Amy Oakland.

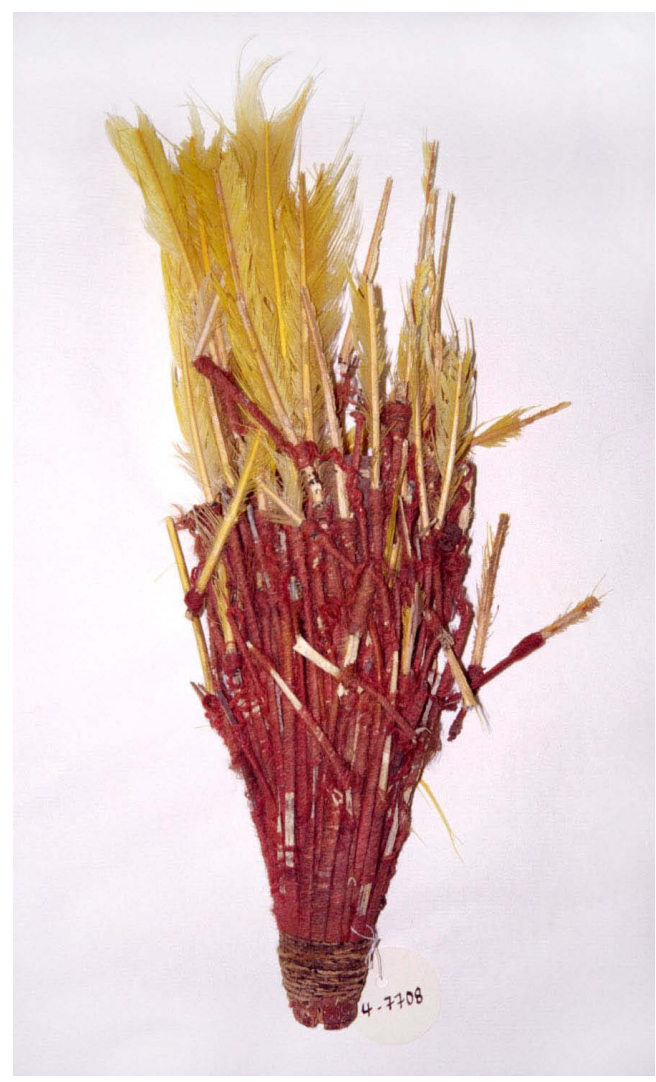

Figure 13. Headdress ornament cataloged as "Bunch of plumes" 4-7708. Courtesy of the Phoebe A. Hearst Museum of Anthropology and the Regents of theUniversity of California. Photo Amy Oakland.

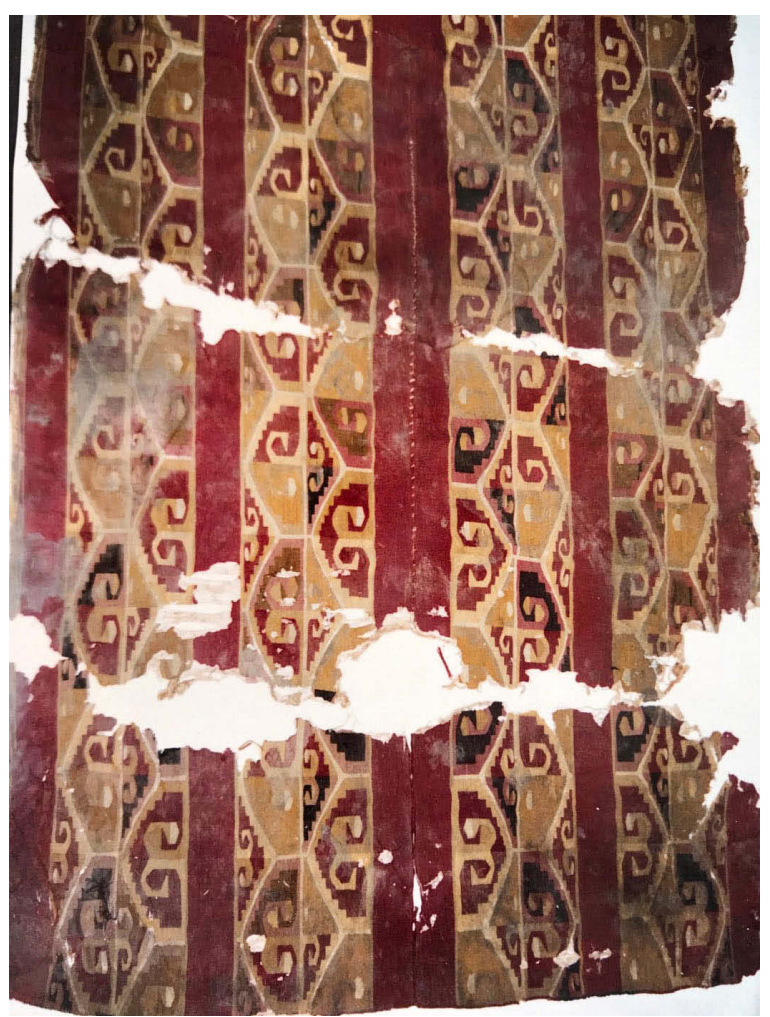

Figure 14. Wari weft-interlocked tapestry man's tunic 4-7825 opened for burial that Uhle cataloged as "Large red and yellow tapestry poncho". Courtesy of the Phoebe A. Hearst Museum of Anthropology and the Regents of the University of California. Photo Amy Oakland. 


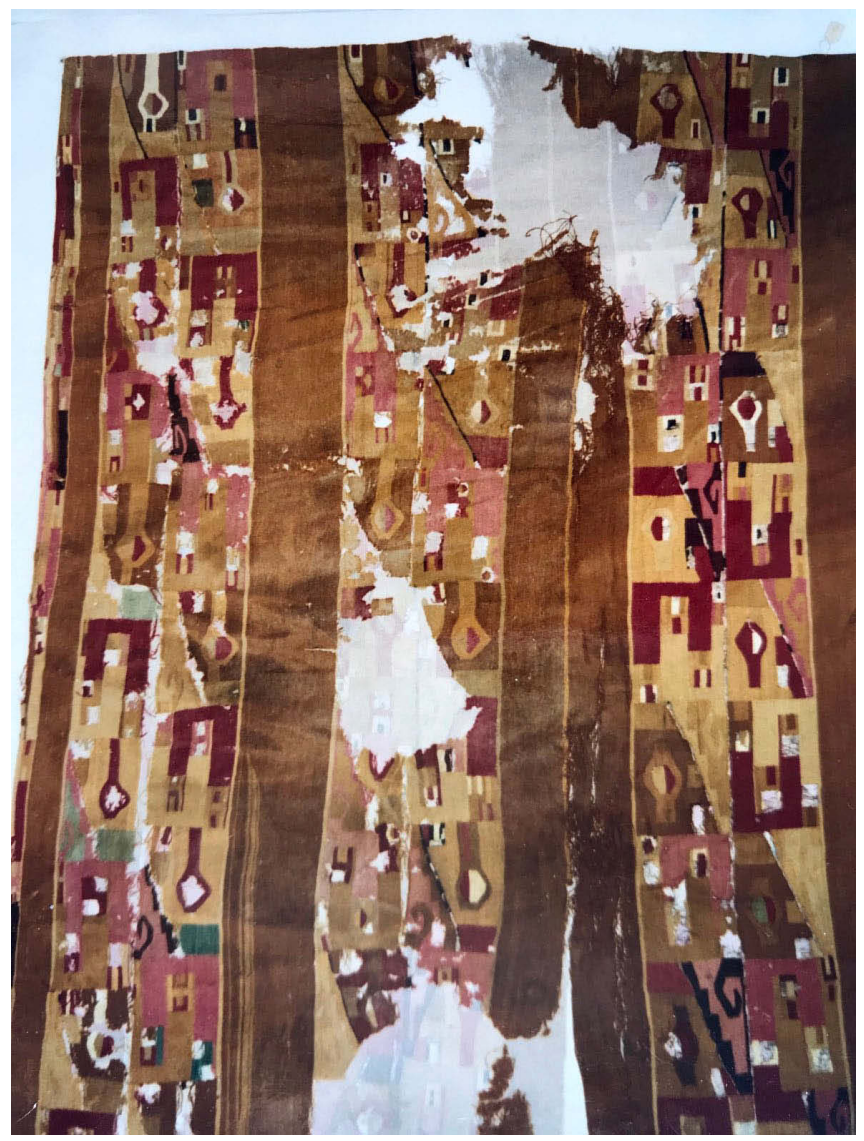

Figure 15. Detail of Wari weft-interlocked tapestry tunic 4-7771 cataloged as "Large tapestry poncho" along with Wari wig 4-7772 in possible Grave 32 from Chimu Capac. Courtesy of the Phoebe A. Hearst Museum of Anthropology and the Regents of the University of California. Photo Amy Oakland.

loomend chained and placed together along the vertical center and the cut end braided and covered with figure- 8 embroidery along the sides. The tunic $4-7825(52.3+52.6 \times 172$ $\mathrm{cm}$ or $86 \mathrm{~cm} . \mathrm{x} 104.9 \mathrm{~cm}$. as worn) is woven with Z2S cotton warp and $\mathrm{Z} 2 \mathrm{~S}$ camelid fiber weft. The design and coloring are familiar for Wari style with red solid vertical bands and repeating and opposing step-fret symbols woven in fine interlocked tapestry.

Uhle listed another Wari weft-interlocked tunic 4-7771 (Figure 15) as "large tapestry poncho" (Menzel 1977: Fig. 75). The tunic 4-7771 (48.7+48 x $206 \mathrm{~cm}$ or $103 \mathrm{~cm}$. $\times 96.7$ $\mathrm{cm}$. as worn) is woven in the same manner with two long, rectangular webs woven on short, cut warps. The design arrangement is the same, with four vertical patterned bands between solid pale brown vicuna-colored sections. The warp in tunic 4-7771 was prepared with both Z2S cotton and camelid-fiber.

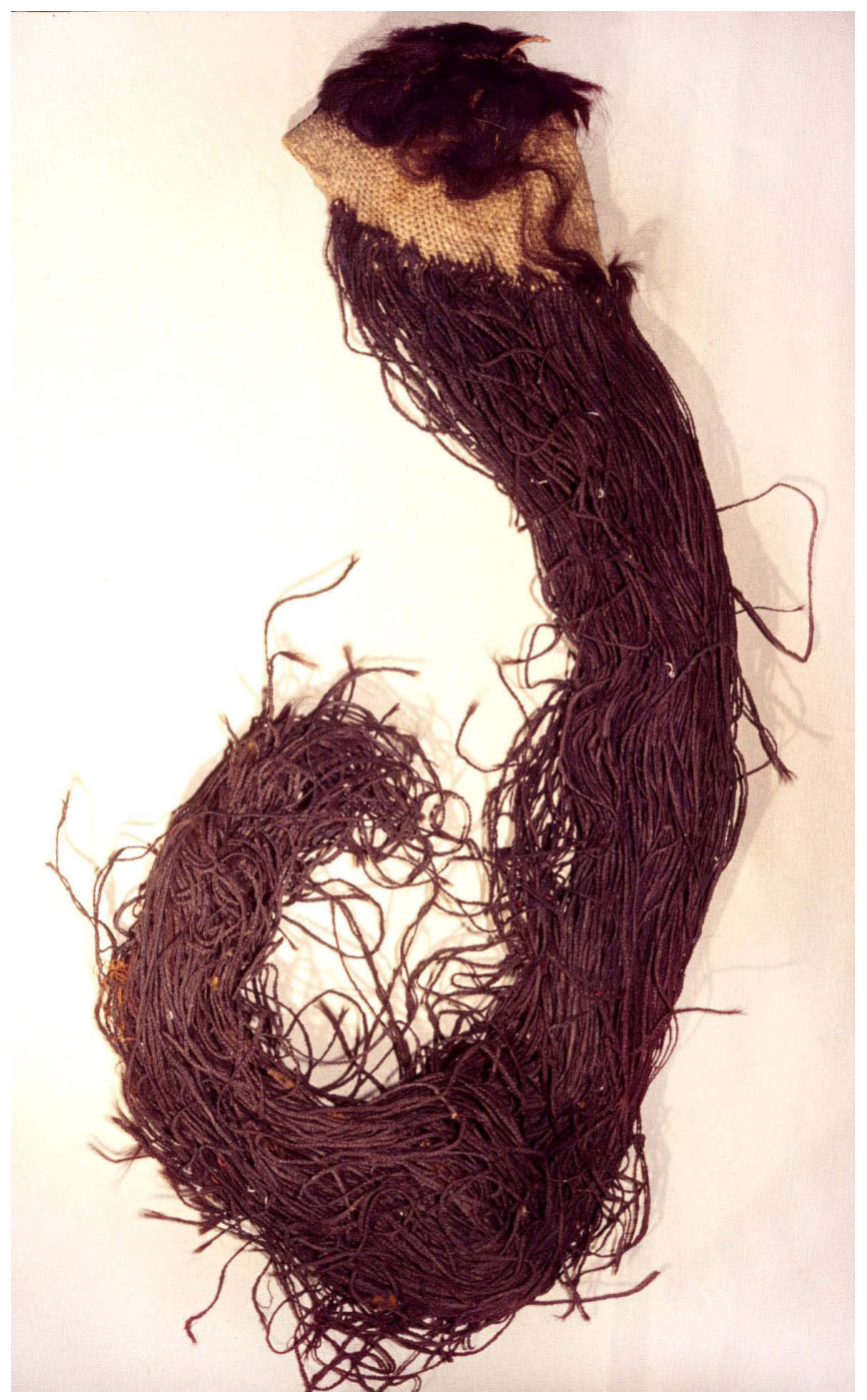

Figure 16. Wari style wig 4-7772 cataloged with a series of objects including miniature textiles, woven pouches, and Wari tapestry tunic 4-7771. Courtesy of the Phoebe A. Hearst Museum of Anthropology and the Regents of the University of California. Photo Amy Oakland.

Wari Wig 4-7772 and Four-Part Headdress Border 4-7779

The catalog numbers that follow this Wari tunic 4-7771 appear consistent with objects that may have constituted a tomb lot here called Grave 32 including a "wig of natural hair" 4-7772 (Figure 16). This Wari type is also known from excavations in Ancon (Reiss and Stübel 1880-1887: Fig.16) and El Castillo (Prümers 1990: Fig. 270). The Chimu Capac wig is formed from a Z2S cotton cap made of simple looping. Thick hanks of human hair are attached through the top of the cap and more than 250 humanhair strands were braided from the bottom cap edge reaching a length of $111.5 \mathrm{~cm}$. Following the wig, Uhle cataloged the painted pouch 4-7773 (Figure 7) described above 


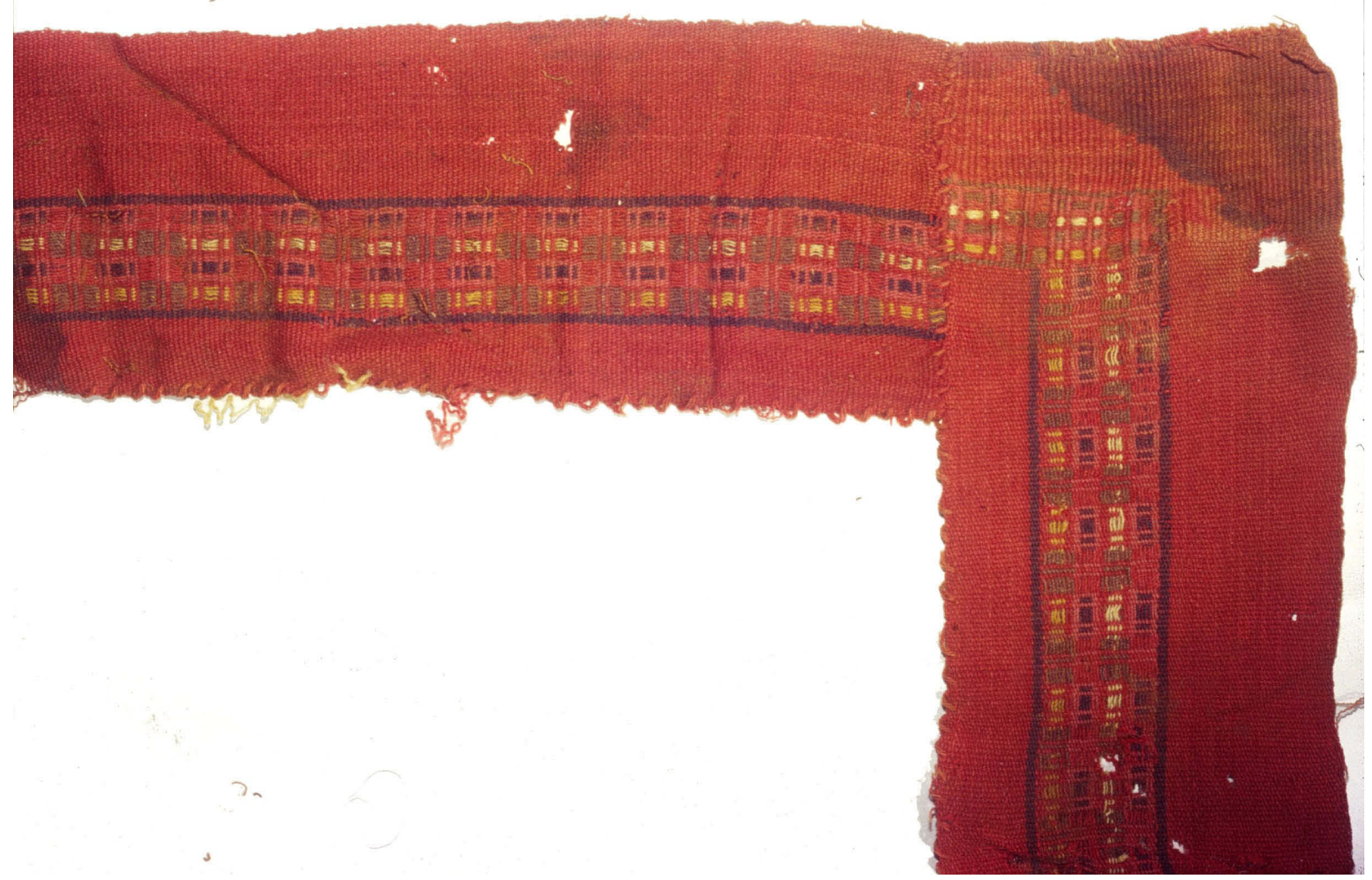

Figure 17. Detail of two sides of headdress border 4-7779 that has been re-used for burial and cataloged as "wrapped around the neck of the mummy", probably the mummy in possible Grave 32 with the Wari tunic 4-7771 and wig 4-7772. Courtesy of the Phoebe A. Hearst Museum of Anthropology and the Regents of the University of California. Photo Amy Oakland.

and 4-7774, 4-7775 described above (Figure 8). The warpstriped miniature tunics 4-7776-7778 must have also accompanied this burial.

Next, Uhle cataloged 4-7779 (Figure 17) that consist of two bands sewn together re-used for burial. He wrote in the catalog that he found this textile "Wrapped around the neck of the mummy". The bands are two sides of the border of a four-part headcloth like those described and illustrated by Young-Sanchez (2006) from Ancon, Chimu Capac, and other Middle Horizon burial locations from the central coast. The two sections ( $107 \times 9.5 \mathrm{~cm}$. and $98 \times 9.5 \mathrm{~cm}$.) illustrated in Figure 17 have been preserved in good condition for approximately $30 \mathrm{~cm}$. on each side of one corner. The ends of the band are complete, but brittle and creased as if just removed from the bundle. The image detail shows the particular feature of this band where the two border sections meet. The weaving structure changes from warpfaced with warp stripes and floats to weft-faced with supplementary weft floats and discontinuous wefts to suggest a continuous pattern around the corner.

Uhle collected a second very similar border fragment from Chimu Capac cataloged simply as "Red woolen fabric" 4-7610 (Young-Sanchez 2006: Fig. 20). This band is slightly wider and shorter and was woven in the same way as 4-7779 with both warp and weft stripes and float patterns. Very few of these four-part headdress cloths were placed intact in Middle Horizon burials. Instead, the borders were removed and divided in half and the four-equal center squares were separated saving only the single decorated square. Only one border has been preserved attached to a part of the original center (Young-Sanchez 2006: Fig. 12). (8)

8. Oakland and Fernandez (2005: Fig.16) illustrate a woman's mantle with the same camelid-fiber warp-face border construction, but the center is a single cotton square. 


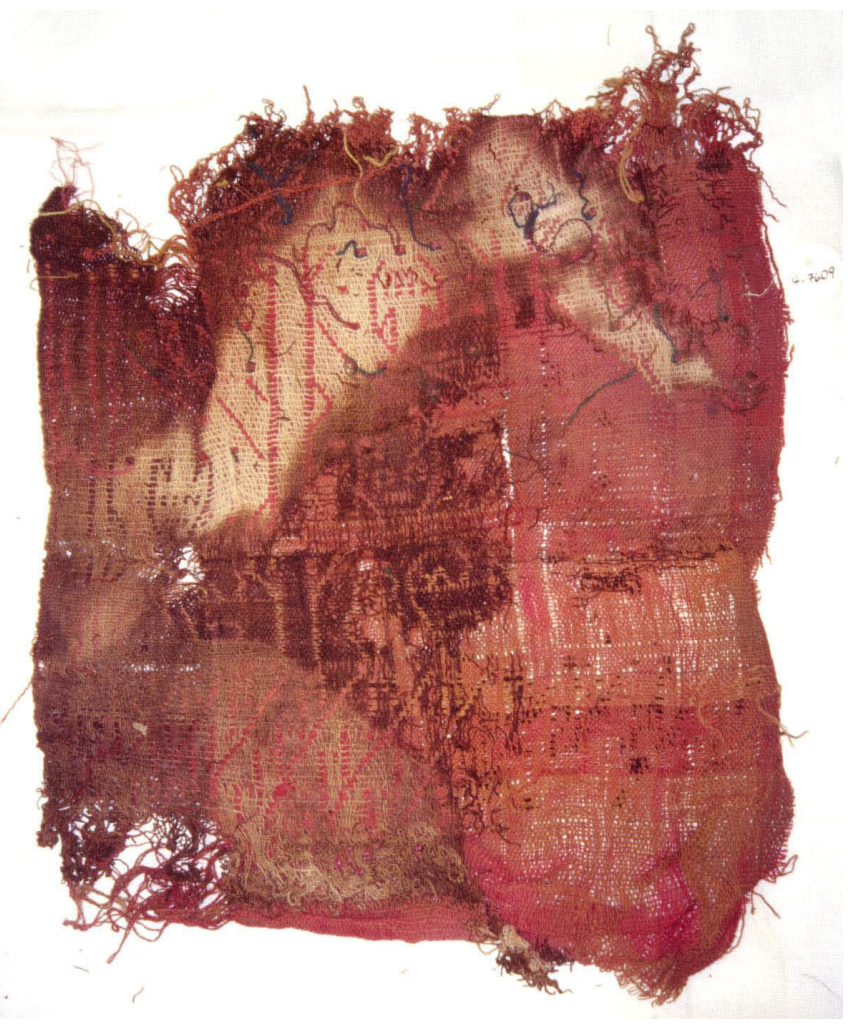

Figure 18. Double cloth square 4-76og cataloged "Red double stuff, San Nicolas" that is one of the four parts woven for the center of a four-part headdress. Courtesy of the Phoebe A. Hearst Museum of Anthropology and the Regents of the University of California. Photo Amy Oakland.

\section{Four-Part Headdress Panels 4-7609 and 4-7489}

The double cloth square $(41.5 \times 32.5)$ that Uhle cataloged 4-7609 "Red double stuff" (Figure 18) may have been discovered together with the band 4-7610 just described. The cloth is woven in $\mathrm{Z} 2 \mathrm{~S}$ red camelid-fiber and white cotton double cloth with discontinuous spots of color similar to at least five more double cloth square textiles that Uhle collected at Chimu Capac.

Uhle cataloged two slightly smaller $(36 \times 32 \mathrm{~cm}$. and 39 $\mathrm{x} 33 \mathrm{~cm}$.) square textiles with the same number $4-7489$ as "Fragments of red double stuff" (Figure 19). The holes remaining in the textile identify the pattern of repeating frets in diagonal rows. These two could have been part of the same textile, and each preserves part of a white plain weave section along one loomend, but the dimensions and patterns suggest that these represent two different headcloths, each with the decorated part that would have been connected with three other plain weave squares to form a fourpart center with decorated borders. Another panel (not pictured) 4-7704 ( $46 \times 46.2)$ was cataloged as "Fragment of red double stuff" with only the red side preserved, very similar to the panels 4-7489. Prümers (1995:353) discusses these diagonally woven designs in red and white double cloth from the central coast with Middle Horizon 3 and 4 associations. For this time period he notes the addition of embroidered, instead of woven color "spots" also noticed by Young-Sanchez (2006: 93).

\section{Unique Chimu Capac Four-Part Headdress Panels 4-7492 and 4-7747}

The Chimu Capac collection includes at least two more variations of four-part headcloth centers. One double cloth fragment 4-7492 (Figure 20) "Red and black double stuff with snake pattern" was woven with similar proportions (41 $\mathrm{x} 38 \mathrm{~cm}$.), although incomplete on three sides. The textile is woven with four color bands of two different color combinations: red camelid fiber and white cotton and purple camelid fiber and white cotton. All yarns are spun and plied Z2S. The designs repeat with profile animals with curled snout and tail, a four-part design ending with snake heads, and a border of frets along one side. A portion of a white $\mathrm{Z} 2 \mathrm{~S}$ cotton cloth is visible along one loomend.

Another complete square ( $47 \times 46 \mathrm{~cm}$.) textile 4-7747 "Fragment of a double fabric" (Figure 21) was woven in light brown and white cotton double cloth and is the only Chimu Capac example with evidence of all four sections of the four-part headcloth. The cloth repeated two white plain weave squares, one brown, and one brown and white double cloth square. The double cloth pattern repeats central images of interlocking snakes with smaller bird figures, serrated fish, and a fret border along the side and bottom. In this textile the camelid-fiber color spots were woven into the cloth along with the double cloth construction in discontinuous wefts over supplementary warps, a Moche textile type identified by Conklin (1979) and a textile structure that Prümers (1990, 1995, 2001) calls Moche-Huari for Middle Horizon textiles from El Castillo.

\section{Double cloth Sleeved Shirt 4-7702 and 4-7702B with Wari Tapestry}

At Chimu Capac, Uhle collected textiles woven in double cloth that appear different to the four-part squares. This textile group is woven with S-spun single cotton yarns paired in warp and used as singles alone or sometimes also paired in the weft. These yarn and weave constructions differ from the Z2S cotton yarns of the central and south coast, but Middle Horizon period north coast spinners spun $S$ yarns and used these as singles in warp and weft noted in MocheHuari textiles at El Castillo (Prümers 1990, 2001). At Chimu Capac Uhle collected many textiles woven in this north coast 

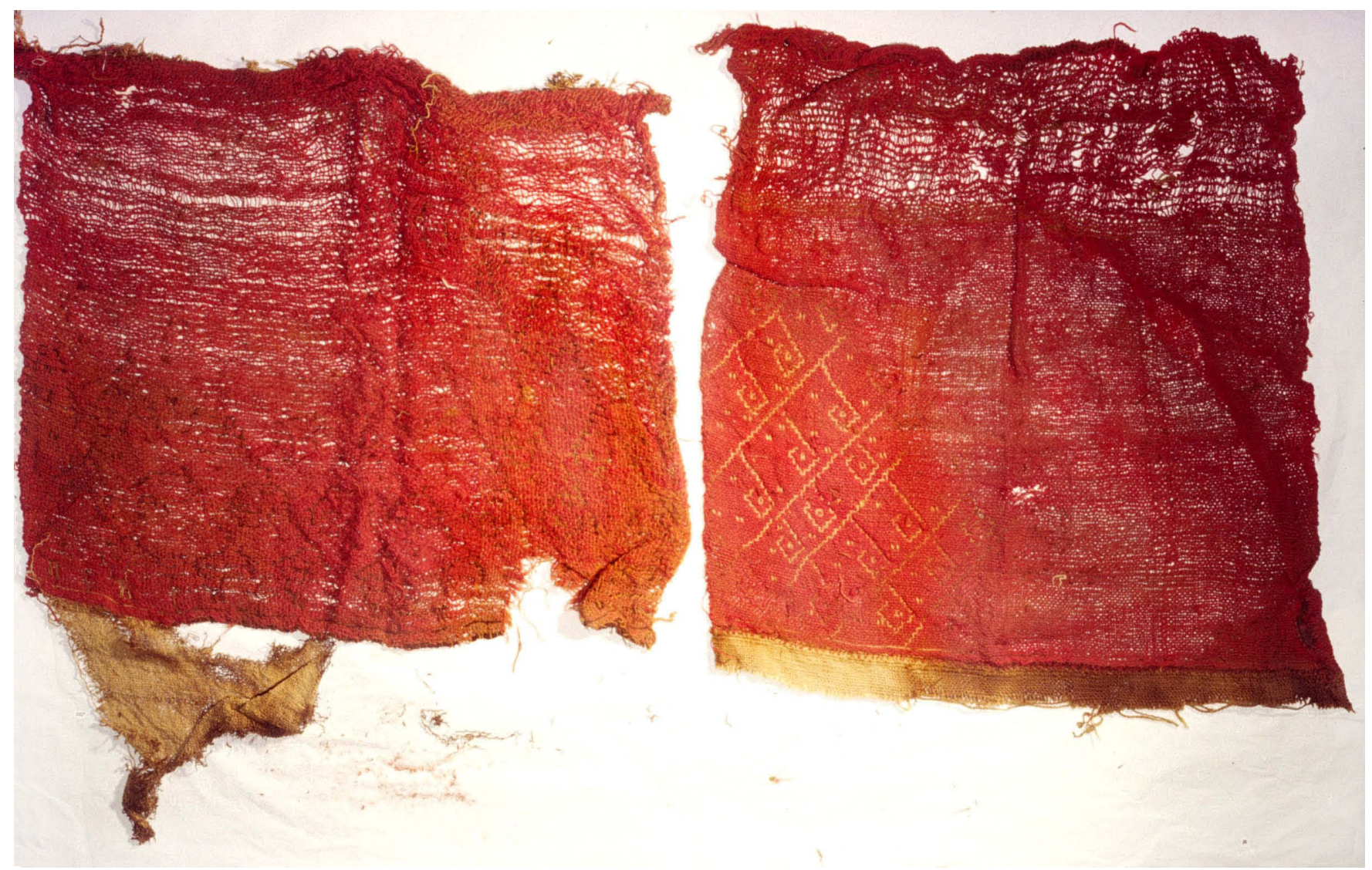

Figure 19. Two different double cloth headdress squares cataloged with the same number 4-7489 "Fragments of red double stuff". Courtesy of the Phoebe A. Hearst Museum of Anthropology and the Regents of the University of California. Photo Amy Oakland.

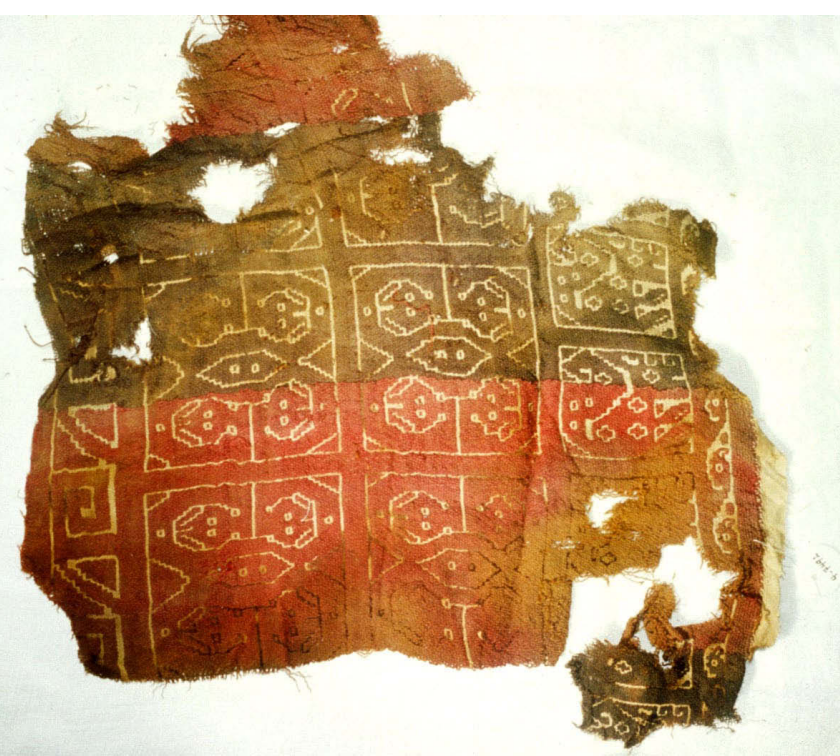

Figure 20. A unique double cloth square possibly woven as one part of a four-part headdress. Uhle cataloged the square "Red and black double stuff with snake pattern". Courtesy of the Phoebe A. Hearst Museum of Anthropology and the Regents of the University of California. Photo Amy Oakland.

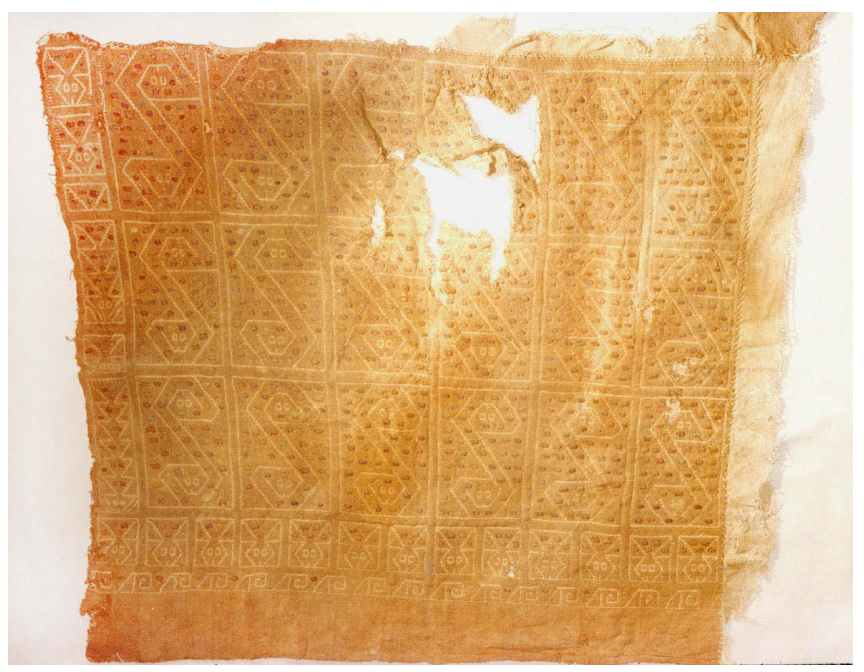

Figure 21. Cotton four-part headdress square 4-7747 with evidence of all four other parts cataloged as "Fragment of a double fabric". Courtesy of the Phoebe A. Hearst Museum of Anthropology and the Regents of the University of California. Photo Amy Oakland. 


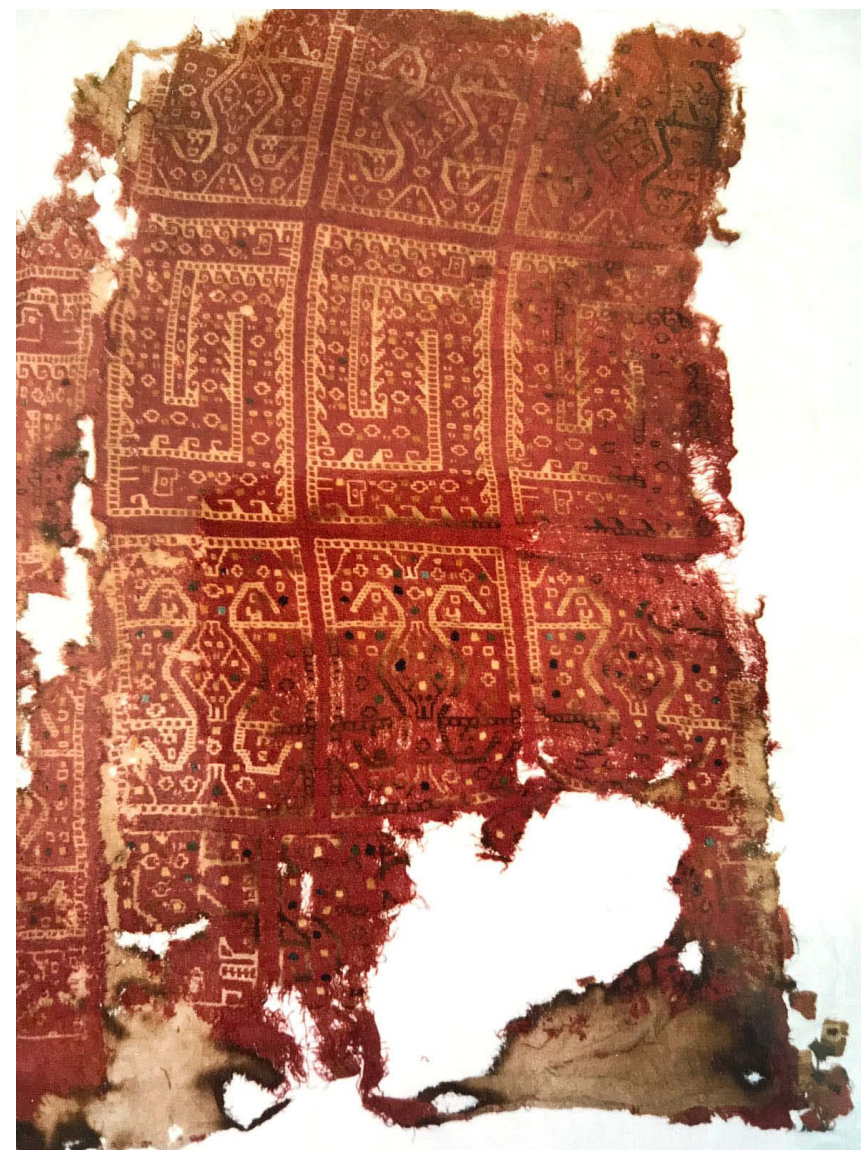

Figure 22. Detail of large section of 4-7702A the front of a sleeved shirt woven in fine double cloth panels with small fragments of highland Wari-style tapestry attached to the bottom corners and sides. Courtesy of the Phoebe A. Hearst Museum of Anthropology and the Regents of the University of California. Photo Amy Oakland.

red and white double cloth style such as a panel 4-7484 cataloged "Red double stuff with animal figures, epigonal style" (Oakland 2001: Fig. 25). Another similar double cloth textile from Chimu Capac 4-7491(not pictured) "Double stuff with brown animal figure” was woven as a rectangle, folded, and used as a sleeve. The cloth is all cotton in brown and white double cloth patterned with the same cat-like animal image.

The textiles illustrated here 4-7702A, and 7702B (Figure 22, 23) cataloged "Large poncho of red and white double stuff, incomplete, and sleeve" are important because they combine highland weft-interlock tapestry and coastal style double cloth. The wide $(95 \times 100.5 \mathrm{~cm}$ ) shirt 4-7702A has been preserved on one face woven in two vertical panels with three vertical design rows that repeat a curled snout and tail animal, double-headed snakes, and a large fourpart design. The sleeve (Figure 22) 4-7702B was woven as a single folded rectangle $(18 \times 16 \mathrm{~cm}$.) with one large

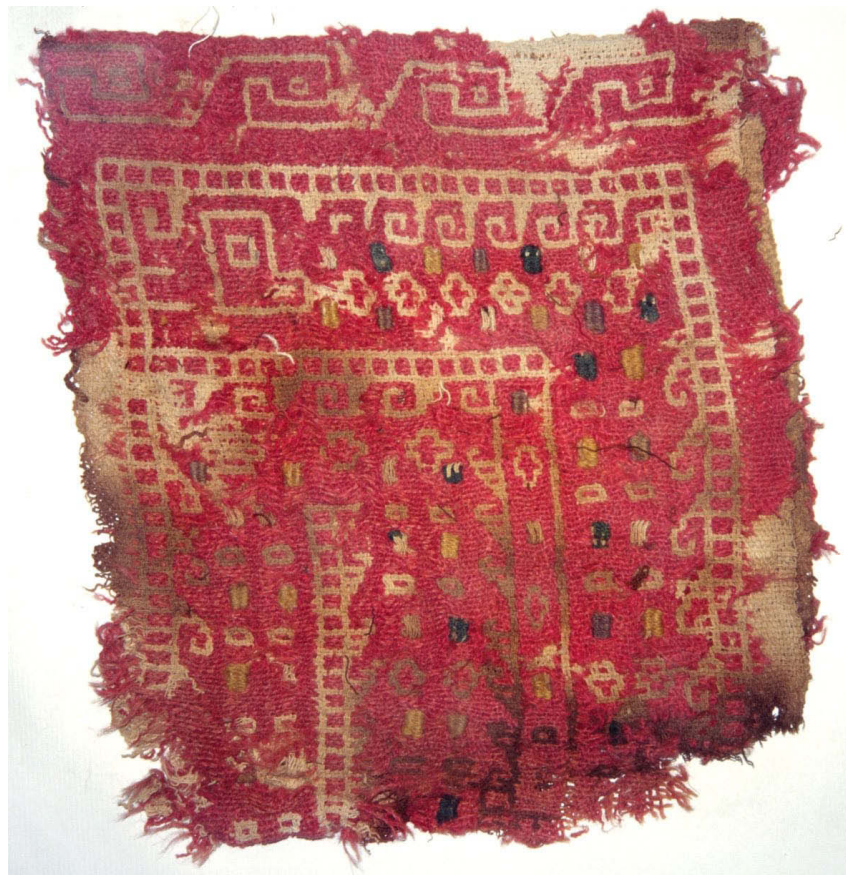

Figure 23. The double cloth sleeve 4-7702B of the large doublecloth shirt 4-7702A cataloged together as "Large poncho of red and white double stuff, incomplete, and sleeve." Courtesy of the Phoebe A. Hearst Museum of Anthropology and the Regents of the University of California. Photo Amy Oakland.

double-headed snake image. In both the shirt and sleeve the white cotton portion of the double cloth was woven with SS/ SS north coast construction with S-spun single yarns here paired in warp and weft with red Z2S camelid fiber double cloth. Discontinuous-weft "spots" in camelid fiber dyed gold, blue, green, and black were woven over supplementary warps. The designs are similar on the two panels, but the execution, color, and block size are dissimilar and the designs do not match between panels. These features suggest that each panel was woven by a different weaver. Fragments of fine camelid fiber weft-interlocked tapestry were sewn to the bottom sides of each panel identifying contemporaneity during the Middle Horizon also noted by YoungSanchez (2000).

\section{Slit-Tapestry Panel 4-7502}

In addition to double cloth, Uhle collected examples of coastal style slit-tapestry in burials at Chimu Capac, many that were woven with north coast style S-spun cotton yarns like 4-7502 (Figure 24). The textile cataloged as "Tapestry fragment" is a wide $(26.3 \times 58 \mathrm{~cm}$.) tapestry panel. Two rows of cross-knit loop stitch embroidery have been stitched over a part of the left side of the panel suggesting the edge finish of a neck or arm opening. Fine camelid fiber slit tapestry has been worked over six S-spun brown cotton yarns 


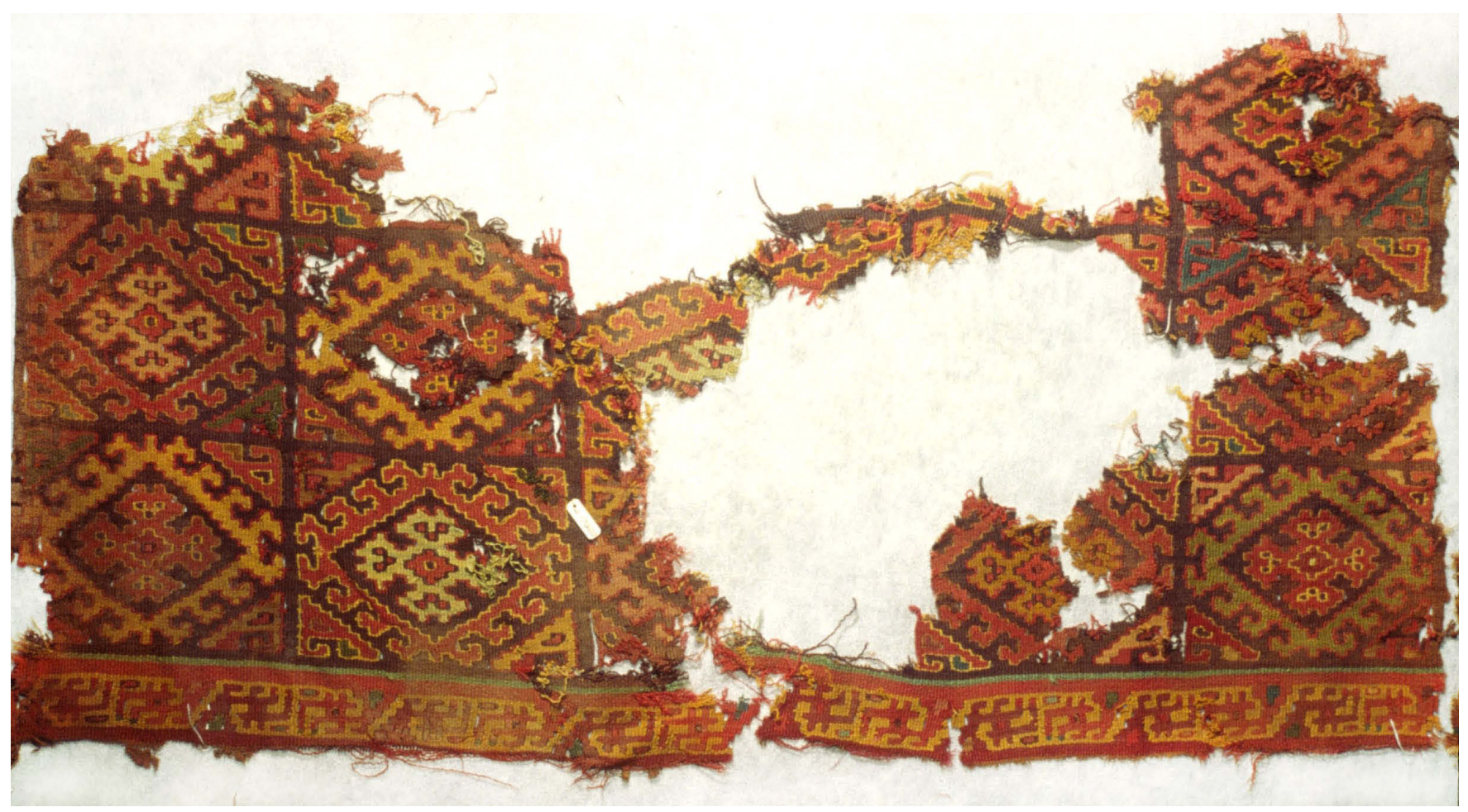

Figure 24. The decorated slit-tapestry portion 4-7502 "Tapestry Fragment" woven over the warp of a cotton plain weave textile visible above and below the fragment excavated by Max Uhle at Chimu Capac. Courtesy of the Phoebe A. Hearst Museum of Anthropology and the Regents of the University of California. Photo Amy Oakland.

grouped together originating from SS/S cotton plain weave below the pattern and visible along the torn bottom edge. The design of both the main block and the border are common to textiles of this period from El Castillo (Prümers 1990: Fig. 134), from Pachacamac (Kaulicke 2001: Figs. 3335; Penn Museum online 29683 "from beneath the temple") and from Huaca Malena where the image is recognized "relacionado con la costa central y la tradicion Huarmey" (Angeles and Pozzi-Escot 2001: Fig. 21).

\section{Slit-Tapestry Fragments 4-7496B, 4-7513}

Uhle gave the same name "Tapestry fragment" to at least ten slit-tapestry textiles like the textile 4-7513 (Figure 25) and two other bands cataloged 4-7496B (not pictured) that were given different numbers, but are borders of the same textile. (9) The fragment 4-7513 was woven on a warp of white S-spun cotton plied S2Z and was created as the side border for a SS/S white cotton plain weave cloth that is visible on one side. The openwork sections of slit-tapestry in 4-7513 are oriented horizontally above and below the figure. This tiny woven figure appears to be a principal Chimu Capac God as Menzel (1977) suggested. Many variations and associated features accompany this individual, but he most often is represented as male with legs spread to each side, genitals prominent, arms spread out and lifted, and sometimes, as in this image he wears a belt. The extremely fine spinning allows for much detail in this small image that is no more that $6 \times 8 \mathrm{~cm}$ tall. The figure stands inside an outlined square with rays or appendages ending in bird heads on each corner and other animal heads are attached to the sides.

Rectangular sections of openwork tapestry between slittapestry designs at Chimu Capac were used as borders on the sleeved shirt 4-7827 analyzed by O'Neale and illustrated by Menzel (1977:Fig.76B and in color by Isbell and YoungSanchez: Fig. 248). It is used in a sleeve border 4-7701C, (Menzel 1977: Fig.77) that was collected with a longer band of the same technique, and also the border of a discontinuous-warp and weft sleeved shirt 4-7789 (not pictured). Narrow bands with this same technique have been noted for collections from El Castillo (Prümers 1990: Figs. 56, 59, 66, $67,70,74,75$ ), Pachacamac (29681 "from beneath the temple" Penn Museum online), and from Huaca Malena (Angeles and Pozzi-Escot (2001: Fig.21). 


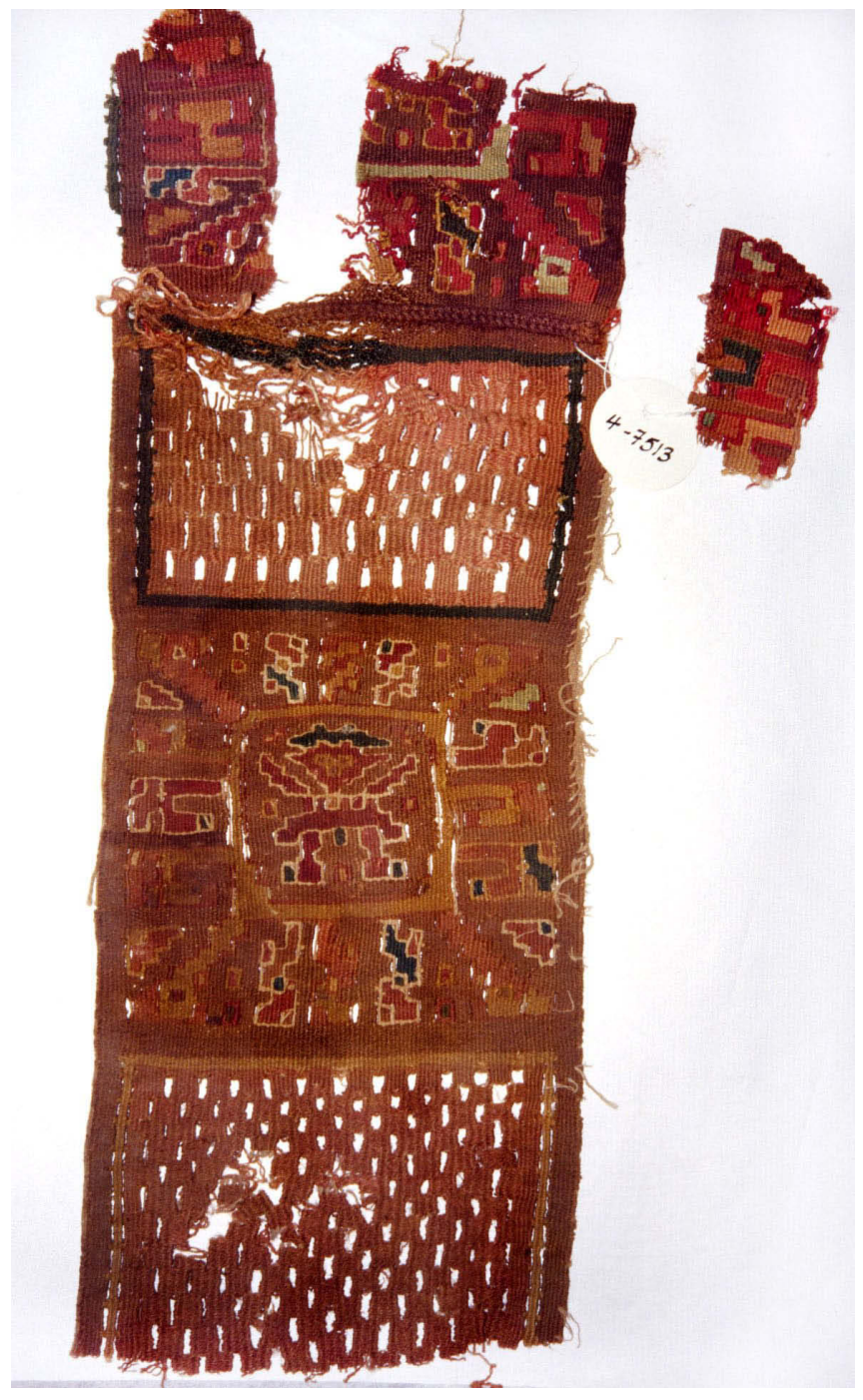

Figure 25. A fragment of openwork and slit-tapestry 4-7513 that was undoubtedly a border to the same plain weave textile with bands woven of the same image cataloged as 4-7496A. The tiny central figure woven in slit-tapestry is the most important icon at Chimu Capac modeled on ceramics and painted on large cloth. Courtesy of the Phoebe A. Hearst Museum of Anthropology and the Regents of the University of California. Photo Amy Oakland.

\section{Chronology and Radiocarbon dates}

Three Chimu Capac textiles 4-7221, 4-7165, and 4-7283 were chosen for radiocarbon dating, each recorded in graves with other textiles and associated material. All three of these textiles represent the types of pouches and painted textiles that are among the best-preserved textiles at the site. This group appears to have been specifically woven for burial and placed freshly made on and around the funeral bundles that Uhle describes in his field notebook. It is assumed that these plain weave types record the final period of interment for most burials in the terraces at Chimu Capac.

In the notebook Uhle records finding the painted textile 4-7221 (Isbell and Young-Sanchez 2012: Fig. 246; Menzel 1977: Fig. 57; Oakland 2010: Fig. 17) along with ten other painted textiles in Grave 15 "next to the mummy, underneath a painted drum, a bundle of many painted cloths". This textile 4-7221 was woven in two webs with Z2S cotton and it has been dated to AD 920-1020. (10) Four other painted textiles included in this large burial were woven with Z2S construction in warp and weft. The other six were formed each using different combinations in warp or weft: S/ZZ, SS,Z/Z, Z/Z, Z,Z2S/Z, ZZ/ZZ, ZZ/Z2S.

Another painted textile that has been dated from Chimu Capac is the large $(128 \times 67 \mathrm{~cm})$ well-planned and executed textile 4-7165 from Grave 12 (Oakland and Fernandez 2001: Figs. 20). Uhle found the large cloth together with two excellently preserved painted textiles (Oakland and Fernandez 2001: Figs. 21, 22). In the notebook he described this burial "the lowest mummy $x$, which had been destroyed, around 3 meters deep". The textile 4-7165 shares a similar iconography with the two other two painted textiles in the tomb. All are painted with two identical figures, but each painting shows a completely different style. The artist of textile 4-7165 painted the two figures in medium brown and lighter brown to fill most of the textile in solid color with the white cotton cloth for detail and as outline. The two principal figures stand facing one another with heads and feet in profile and body in front view and each hold a staff in front. A band of interlocking steps creates a border on three sides. The cloth was woven with both $\mathrm{Z}$ and S-spun single cotton yarns used in warp and weft. This textile was dated AD 96o-110o. (11) The painted pouch 4-7283 (Figure 6) from Grave 25 described above was also dated to a similar late Middle Horizon period, AD 9401020 (see note 7 ).

10. Painted textile 4-7221 yielded age 970+/-50 for CAMS55927. CAMS, Lawrence Livermore National Laboratory, June 1, 1999. “Quoted age is in radiocarbon years using the Libby half life of 5568 years and following the conventions of Stuiver and Polach, Radiocarbon, v. 19 , p.355, 1977".

11. Painted textile 4-7165, one of three painted textiles from Grave 12 (Oakland 2001: Fig. 20, 21, 22) yielded age 1030+/-70 for CAMS55926. CAMS, Lawrence Livermore National Laboratory, June 1, 1999. "Quoted age is in radiocarbon years using the Libby half life of 5568 years and following the conventions of Stuiver and Polach, Radiocarbon, v. 19, p.355, 1977. Comment: The larger uncertainty in CAMS55926 (4-7165) result is due to the small sample size". 


\section{Discussion}

The Late Middle Horizon period represented at Chimu Capac by these painted textiles and "medicine pouches" may not be, and indeed probably is not the same period represented by all of the textiles and ceramics that were placed in Chimu Capac tombs. Menzel (1977) noted ceramics at the site from all Middle Horizon epochs, but most pertaining to $\mathrm{MH} 2 \mathrm{~B}$ and 3. Wari interlocked highland tapestry and associated coastal styles like the red and white double cloth sleeved shirt 4-7702A and B (Figures 22, 23) discussed above undoubtedly relate to earlier burials and perhaps original clothing that was repurposed for the final internment in Chimu Capac graves. In contrast to the well-preserved plain weave made for burial, Uhle excavated many fragments of coastal tapestry and double cloth that was already worn and deliberately torn and cut. Highland styles such as Wari tunics also identify wear and repair as well as alterations for burial. Other highland garment types and additional Wari fragments such as knotted pile headbands and tie-dye textiles also derive from distant locations and undoubtedly earlier periods of use.

Textile preservation was excellent and the textile types collected at the site and discussed in this article will help establish contemporary Middle Horizon groups like those identified at Chimu Capac for ceramics by Menzel (1977) and outlined recently for the Middle Horizon by Eeckhout (2018:541-553). One important aid for scholars working with textiles from the Peruvian coast is the identification of long-standing coastal traditions in the simple method of spinning cotton. The S spinning traditions using the horizontally-held spindle have been described and illustrated by Vreeland (1986) for the contemporary north coast and by Ann Rowe (1984) for Late Intermediate Period Chimu textiles. This same tradition was used earlier on the north coast by Early Intermediate Moche spinners and weavers (Prümers 1995) and in Moche-Huari textiles from El Castillo in the Huarmey Valley (Prümers 1990; 1995; 2001). Many Chimu Capac textiles use this north-coast S spinning method and pair S single yarns in the warp and use S spun yarns as singles in the weft SS/S.

Uhle knew that he had discovered material from both northern and southern styles at Chimu Capac and he wrote Phoebe Hearst that:

"The ancient remains in the graves of the old town Chimu Capac are memorable for one more important circumstance in the development of my archaeological studies. The ruins of Chimu
Capac, about half way between Pachacamac and Trujillo are now memorable because in their graves both these early civilizations, that of the North and that of the South are meeting" (Uhle 1905: 10-11).

He was comparing ceramic types, but he found similar textiles at Pachacamac. Middle Horizon spinners on the central and south coast produced $Z$ spun yarn from the top, not the tip of spindles and these are usually plied Z2S as VanStan (1967) identified for Pachacamac. Many Chimu Capac textiles and most pouches were woven Z2S, perhaps a measure of the local style of plain weave at Chimu Capac like other central and south coast Middle Horizon funerary textile collections such those from Ancon (Young-Sanchez 2000) and Huaca Malena (Angeles 2017; Angeles and PozziEscot 2001; Frame and Angeles 2014).

At Chimu Capac the painted textiles are a very different group, not unique to the site, but exceptional in the 155 excavated in a single location. The yarn and weave structures are also very unusual with more than 65 different yarn combinations using either S or Z spun yarns or both and woven structures in single yarns, plied yarns and paired single and plied yarns, sometimes all at once in the cotton plain weave base cloth. Since archaeological excavations have not yet identified any Middle Horizon habitation site, it remains difficult to define the local textile style that would relate to a resident population in the lower Supe Valley. The excavations that Max Uhle made in 1904 provide the only evidence for Middle Horizon period activity at Supe and the contents of his excavation pertain specifically to funerary remains. For burial rituals it appears that people using traditions from both the north and the south were possibly together at the site to weave the cloth for painted textiles.

The mummy bundle form and many of the woven textiles are similar to those described for other communities along the Pacific coast of Peru during the Middle Horizon identifying people in the lower Supe Valley who practiced many of the same burial rituals at Chimu Capac. This article has been prepared to add to the analyses of the many investigators working today on similar collections from the same period and burial tradition.

\section{Acknowledgments}

This study began in 1989 and I was fortunate from the beginning to have worked with Nancy Porter at the Phoebe Apperson Hearst Museum of Anthropology. At the museum I appreciate the aid of Leslie Freund and all others who made objects available for 
analysis and to the Museum Staff who gave me permission to publish the images of the Chimu Capac collection. At California State University East Bay Malka Helfman helped in digitizing the original research slides. The work with Middle Horizon funeral bundles at Huaca Cao with John Verano, Vuka Roussakis, and Arabel Fernandez sponsored by the National Endowment for the Humanities during 1998-200o greatly expanded my understanding of the Chimu Capac collection. I appreciate the encouragement from the editors Lena and Ann and the two anonomous reviewers who helped focus this article. My most profound gratitude goes to Heiko Prümers who gave me permission to use his translation of Max Uhle's Supe Notebook 67 and to the Ibero-American Institute, of the Prussian Cultural Heritage Foundation, Berlin for their kind permission to publish the notebook.

\section{References Cited}

Angeles, Rommel

2017 Tocados del Horizonte Medio al Intermedio Tardio en la coasta central: Una vision desde el valle de Asia, Peru (Siglos VII-XII d.C.), PreColumbian Textile Conference VII (2016), edited by Lena Bjerregaard and Ann Peters, pp. 277-307.

Angeles, Rommel and Denise Pozzi-Escot

2001 Textiles del Horizonte Medio: las evidencias de Huaca Malena, valle de Asia. In Huari y Tiwanaku: modelos vs. evidencias, primera parte, Boletin de arqueologia PUCP, No.4 (2000), edited by Peter Kaulicke and William Isbell, pp. 401-424. Pontificia Universidad Catolica, Lima.

Carrion Cachot, Rebecca

1959 La Religion en el Antiguo Peru (Norte Y Centro de la Costa, Periodo Post-Clasico), Lima.

Conklin, William

1979 Moche Textile Structures. The Junius B. Bird PreColumbian Textile Conference, May $19^{\text {th }}$ and $20^{\text {th }}$, 1973, edited by Ann Pollard Rowe, Elizabeth Benson and Anne-Louise Schaffer, pp. 165-184. The Textile Museum and Dumbarton Oaks, Trustees for Harvard University, Washington, D.C.

Eeckhout, Peter

2018 The Middle Horizon and Southern Andean Iconographic Series on the Central Coast of Peru. In Images in Action, The Southern Andean Iconographic Series, edited by William Isbell, Mauricio Uribe, Anne Tiballi, and Edward Zegarra, pp. 533-569. UCLA Cotsen Institute of Archaeology Press.

Frame, Mary and Rommel Ángeles Falcón

2014 A female funerary bundle from Huaca

Malena, Nawpa Pacha, 34:1, 27-59, DOI: 10.1179/oo77629714Z.0oooooooo13
Isbell, William and Margaret Young-Sanchez

2012 Wari's Andean Legacy, Wari: lords of the ancient Andes, edited by Susan Bergh, pp. 251-266. The Cleveland Museum of Art, Cleveland and Thames and Hudson, New York.

Kaulicke, Peter

1997 Contextos Funerarios de Ancon, Esbozo de una síntesis analítica. Pontifica Universidad Catolica del Peru, Lima.

2001 La sombra de Pachacamac: Huari en la costa central. In Huari y Tiwanaku: modelos vs. evidencias, primera parte, Boletin de arqueologia PUCP, No. 4 (2000), edited by Peter Kaulicke and William Isbell, pp. 313358. Pontifica Universidad Catolica, Lima.

Kroeber, Alfred

1925 The Uhle pottery collections from Supe, University of California Publications in American Archaeology and Ethnology, 21(6) 235-267.

Menzel, Dorothy

1977 The archaeology of ancient Peru and the work of Max Uhle. R. H. Lowie Museum of Anthropology, University of California, Berkeley.

Oakland, Amy

2010 Telas pintadas de Chimu Capac, valle de Supe, Peru. In Max Uhle: evaluaciones de sus investigaciones $y$ obras, edited by Peter Kaulicke, Manuela Fischer, Peter Masson and Gregor Wolff, pp. 281-293. Fondo Editorial de la Pontificia Universidad Catolica del Peru, Lima.

Oakland Rodman, Amy and Arabel Fernandez

2001 Los tejidos huari y tiwanaku: comparaciones y contextos. In Huari y Tiwaaku: modelos vs. evidencias, primera parte, Boletin de arqueologia PUCP, No. 4 (200o), edited by Peter Kaulicke and William H. Isbell, pp. 119-130. Pontificia Universidad Catolica del Peru, Lima.

2005 North coast style after Moche: clothing and identity at El Brujo, Chicama Valley, Peru. In Us and them: archaeology and ethnicity in the Andes, monograph 53, edited by Richard Reycraft, pp. 115-133. Cotsen Institute of Archaeology, University of California, Los Angeles.

O’Neale, Lila

1933 A Peruvian Multicolored Patchwork. American Anthropologist.

Prümers, Heiko

1990 Der fundort "El Castillo" in Huarmeytal, Peru. Einbertrag zum problem des Moche-Huari textilstils. 2 vols. Mundus Reihe Alt-Amerikanistik, Band 4, 2. Holos Verlag, Bonn. 
Prümers, Heiko

1995 Ein ungewohnliches Moche-Gwebe aus dem Grab des "Fursten von Sipan" (Lambayeque-Tal, Nordperu), Beitrage zur Allgemeinen und Vergleichenden Arquaologie, 15, 309-369.

2001 "El Castillo" de Huarmey: una plataforma funeria del horizonte medio. In Huari y Tiwaaku: modelos vs. evidencias, primera parte, Boletin de arqueologia PUCP, No. 4 (200o), edited by Peter Kaulicke and William H. Isbell, pp. 289-312. Pontificia Universidad Catolica del Peru, Lima.

Reiss, Wilhelm, and Alfons Stübel 1880-1887 The Necropolis of Ancon in Peru: a contribution to our knowledge of the culture and industries of the empire of the Incas, being the results of excavations made on the spot. 3 vols. Translated by A. H. Keane. A. Ascher and Co. Berlin.

Rowe, John

1954 Max Uhle, 1856-1944, A memoir of the father of Peruvian archaeology. University of California Publications in American Archaeology, and Ethnology, Vol. 46, (1).

Rowe, Ann Pollard

1984 Costumes \& Featherwork of the Lords of Chimor, Textiles From Peru's North Coast. The Textile Museum, Washington, D. C.

1986 Textiles from the Nasca Valley at the time of the fall of the Huari Empire. In The Junius B.Bird conference on Andean textiles, April 7 and 8, 1984, edited by Ann P. Rowe, pp. 151-182. The Textile Museum, Washington, D.C.

Uhle, Max

1903 Pachacamac: report of the William Pepper, M.D., LL.D., Peruvian expedition of 1896. Department of Archaeology, University of Pennsylvania, Philadelphia.

1905a Supe Report: "Report on my explorations in the Valley of Supe", (received by Mrs. Hearst October 17, 1905. Unpublished, Phoebe Apperson Hearst Museum of Anthropology, University of California, Berkeley.

1905b Berkeley Catalog: "Beginning of the excavations at San Nicolas near Supe”, received by Mrs. Hearst October 17, 1905. Unpublished, Phoebe Apperson Hearst Museum of Anthropology, University of California, Berkeley.
Valkenier, Lisa

1995 New Evidence for Chimu Capac and the Early Horizon Period In The Supe Valley, Peru. Journal of the Steward Anthropological Society. Vol.23, Nos. 1 and 2: 289-286.

VanStan, Ina

1955 Peruvian domestic fabrics from Supe: a study of the Uhle Collection of Painted Cloths. Department of Anthropology and Archaeology Notes in Anthropology, 1:3. Florida State University, Tallahassee.

1967 Textiles from Peneath the Temple of Pachacamac, Peru: a part of the Uhle collection of the University Museum, University of Pennsylvania. Museum Monographs 7. The University of Pennsylvania, Philadelphia.

Vreeland, James

1986 Cotton Spinning and Processing on the Peruvian North Coast, In The Junius B.Bird conference on Andean textiles, April 7 and 8, 1984, edited by Ann P. Rowe, pp. 363-383. The Textile Museum, Washington, D.C.

Young-Sanchez, Margaret

2000 Textiles from Peru's Central Coast, 750-1100: The Reiss and Stübel Collection from Ancón. Ann Arbor, Mich.: UMI Dissertation Services.

2006 Four-part headcloths from the Peruvian Central coast. In Andean textile traditions: papers from the 2001 Mayer Center symposium at the Denver Art Museum, edited by Margaret Young-Sanchez and Fronia Simpson, pp. 75-98. Denver Art Museum, Colorado. 